\title{
“WAGGING THE DOG”: FEIGNING CRISIS IN U.S. ANTI- MIGRATION NARRATIVES TO CREATE CRISIS ${ }^{1}$
}

\author{
MAUREEN DUFFY ${ }^{2}$
}

\begin{abstract}
54, 40 or fight. What does that mean?...Remember the Maine...Tippecanoe and Tyler, too...They're war slogans Mr. Motss. We remember the slogans, we can't even remember the [f'ing] wars. Y'know why? Cause its show business. That's why I'm here."
\end{abstract}

\begin{abstract}
Anti-migration narratives are sweeping around the world, often accompanied by support for racist ideologies. The narratives usually involve some false claim that those seeking to enter the country are presumptively dangerous. Such narratives are obviously not new, but they are arguably being presented in evolving ways and having evolving, and deeply troubling, practical and legal effects. In the U.S., migrants being held in horrific "camp" conditions represent just the latest in a series of anti-migrant measures, each arguably worse than the last. This phenomenon is not limited to the U.S., but that example provides a strong vehicle for demonstrating this larger transnational trend. This article argues that harmful antimigrant narratives are having significant, adverse effects on human rights and foundational legal norms.
\end{abstract}

KEYWORDS: Narratives; Counter-narratives; Migration; Refugees; U.S. constitutional law.

\footnotetext{
${ }^{1}$ This expression is borrowed from the film "Wag the Dog" as explained more in this section. See Barry Levinson, Dir, Wag the Dog (Baltimore Pictures: 1997)[Wag the Dog]. This article recognizes controversy over terminology in this area, and recognizes controversy relating to the use of the term "migrant." In this article, the word is used to describe people seeking to move from one country to another, without distinguishing as to the reason, with the intent of using a neutral description.

2 Dr. Maureen Duffy is an associate professor at the University of Calgary. Originally from the United States, she holds a Bachelor's degree and Juris Doctor from the U.S. and a Master's and a Doctoral degree in law from McGill University in Canada. She is the author of Maureen Duffy, Detention of Terrorism Suspects: Political Discourse and Fragmented Practices (Oxford: Hart 2018)[Duffy]. Contato: mtduffy@ucalgary.ca.

${ }^{3}$ Wag the Dog, supra note 1.
} 


\section{INTRODUCTION: The DOG CONTINUES TO WAG}

Political narratives do not always describe reality. They can, at times, create it, and they can alter legal narratives in troubling ways if not adequately deconstructed and critiqued.

The 1997 film "Wag the Dog" tells the fictional story about U.S. Government officials creating a fake war. Their story is designed to distract the public and the media from an actual presidential scandal, in which the President has been accused of sexual misconduct involving an under-aged girl. In the film, this scandal is set to break in the media shortly before the election. ${ }^{4}$ Each time the scandal threatens to regain the media's attention, the fictional stories become increasingly ludicrous to continue the distraction. ${ }^{5}$ Obviously, the narrative did not create a war, although it could have, but it did create a sense of reality among some who heard it that this fake war was real. ${ }^{6}$ Had some legal change been undertaken as a result, that change could only be properly assessed by breaking down the underlying political discourse.

The film is intended as dark comedy. The "wag the dog" expression has entered popular U.S. lexicon to suggest even the appearance that a narrative is dishonestly promulgated, and in particular to distract from something else, and the expression has been invoked in recent years. ${ }^{7}$ Thus, while much can be said about the internal use of narratives in the actual film, it has developed an importance for the way the film's message is perceived externally, whether accurate or not. ${ }^{8}$ One author argued that the film marked a "new era" between film and perceptions of political reality in the U.S. ${ }^{9}$

In mid-2019, as U.S. political discourse threatening war with Iran escalated, and calls for presidential impeachment were sounding at the same time, one New York Times editorial noted: "And maybe even Mr. Trump sees promise in a 'wag the dog' strategy in the run-up to the 2020 election, rallying his supporters around a 'wartime' president." 10 Before the 2018 Midterm Elections, Trump made much of a "caravan" of migrants heading to the U.S., suggesting that the caravan represented a national

${ }^{4}$ Ibid.

${ }^{5}$ Ibid.

${ }^{6}$ Ibid.

7 For an in-depth analysis of the film, and of the use of narratives, see Eleftheria Thanouli, Wag the Dog: A Study on Film and Reality in the Digital Age (London: Bloomsbury Academic 2013)(among other things, assessing, in depth, the narrative formulations applied by the film) [Thanouli].

${ }^{8}$ See generally ibid at ch. 1 (for an assessment of the internal narrative of the film).

${ }^{9}$ Ibid at 77.

${ }^{10}$ Wendy R. Sherman, “Opinion: How to Stop the March to War with Iran The New York Times (15 May 2019), online: <https://www.nytimes.com/2019/05/15/opinion/stop-iran-war.html>. 
crisis and leading to the accusation that he was pursuing a "wag the dog" strategy to galvanize his supporters and to distract from problems his party faced in the upcoming elections. ${ }^{11}$ In mid-2019, a media furor arose regarding Trump's Twitter posts, suggesting that four Congresswomen of Colour return to "where they came from," even though three of them were born in the U.S. and the fourth was a naturalized citizen. ${ }^{12}$ Suggestions were made that his comments were obviously racist and intended to create an uproar and to distract from a simultaneously advanced governmental counter-narrative on immigration that was, itself, designed to distract from horrific conditions under which migrants, including children, were being held at the U.S.-Mexico Border. Interestingly, one of the four members of Congress is, herself, a prior refugee to the U.S., and is now a citizen. ${ }^{13}$ The four members of Congress had been vocal about the conditions in the detention facilities, and, when Trump posted his inflammatory comments about them, one of them, Representative Ayanna Pressley, said "[t]his is a disruptive distraction," and encouraged people not to let Trump's comments succeed in distracting from the immigration issue they were trying to keep in the political narrative. ${ }^{14}$ Regardless of whether the intention to distract or deceive is established, the question is now frequently asked, and that form of question itself is embedded into U.S. political narratives.

The larger idea of politicians controlling narratives to achieve particular ends is an old concept. George Orwell famously derided political speech, saying it "is designed to make lies sound truthful and murder respectable, and to give an appearance of solidity to pure wind ..."15 In Chicago, corrupt politics are embedded into the local narrative, and some assert - to a fair amount of dispute - that the nickname "the Windy City"

\footnotetext{
11 See Adam Taylor, “Trump Embraces 'Wag the Dog' Politics” Washington Post (31 October 2018), online: $\quad<$ https://www.washingtonpost.com/world/2018/10/31/trump-embraces-wag-dogpolitics/?utm_term=.3f04fd0eb7e3>.

12 Donald J. Trump, Twitter (14 July 2019), online: $<$ https://witter.com/realDonaldTrump/status/1150381394234941448>(beginning a thread of three tweets).

13 Andrea González- Ramírez, “Don't Let Trump's Racist Tweets Distract You From These Immigration Stories" Refinery29 (15 July 2019), online: <https://www.refinery29.com/enus/2019/07/237856/trump-alexandria-ocasio-cortez-racist-tweets-ice-raids-asylum-policy>

14 Ibid.

15 George Orwell, "Politics and the English Language" (first published London: Horizon 1946, reproduced numerous times since), online: <http://www.orwell.ru/library/essays/politics/english/e_polit>; see also Duffy, supra note 2(detailing significant flaws in political language emanating from the U.S. after $9 / 11$ and its adverse impact on constitutional norms).
}

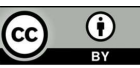


arose as a reference to corrupt politicians blowing hot air. ${ }^{16}$ To "blow hot air" is to speak a lot, without saying anything useful or true. ${ }^{17}$ Regardless of whether that is the true origin of the nickname, a widespread belief among Chicagoans as to the meaning has arguably transformed the original meaning. The perceptions of those hearing a narrative can thus be as influential as the actual intention behind its creation, particularly now, with the Internet amplifying the spreading of narratives, but also allowing audiences to select the messages they want to hear.

Recent scholarship has addressed some specific transnational examples of political false narratives, illustrating that this happens everywhere and can affect a wide range of issues. For instance, one such narrative involved the family of Ferdinand Marcos, who sought to recast the disgraced dictator as a "hero," including burial in a cemetery normally reserved for heroes. ${ }^{18}$ That political narrative was supported by a decision of the Supreme Court of the Philippines, which upheld the decision to allow the burial. ${ }^{19}$ One author suggests that, in purporting to issue a neutral ruling, the Court actually superimposed a false historical narrative over the truth:

The Supreme Court accomplished what Marcos' own writings could not. It rehabilitated the image of Marcos making him the hero that he always wanted to be ... The refurbished judicial version of Marcos is a soldier who defended the country against foreign invaders and not a politician who was responsible for the erosion of Philippine democracy and who pillaged the national coffers. ${ }^{20}$

${ }^{16}$ While the popular perception in Chicago is that this is the reason behind the nickname, it has been credibly disputed by some sources. See eg Robert Cass, “The Origins of the Term 'Windy City' Have Been Misreported (Again)" Chicago Reader (21 November 2008), online: <https://www.chicagoreader.com/Bleader/archives/2008/11/21/the-origins-of-the-term-windy-cityhave-been-misreported-again $\geq$.

17 Wiktionary, <https://en.m.wiktionary.org/wiki/full_of_hot_air>.

18 See Dante Gatmaytan, "Judicial Historical Revisionism," forthcoming, as presented at the conferences of the Law and Society Association of Australia and New Zealand and the Canadian Law and Society Association, June 2019 [Gatmaytan].

19 Ibid (discussing Ocampo v. Enriquez, G.R. Nos. 225973, 225984, 226097, 226116, 226117, 226120 \& 226294, November 8, 2016).

${ }^{20}$ Gatmaytan, supra note 18; see also Onur Bakiner, “'These are Ordinary Things': Regulation of Death under the AKP Regime," in Banu Bargu, ed., Turkey's Necropolitical Laboratory: Democracy, Violence and Resistance (forthcoming October 2019, Edinburgh University Press), as presented at the Canadian Law and Society Association conference, June 2019 (arguing that, to quell public outrage over 
Increasingly, transnational political narratives have spread under the guise of "nationalism." ${ }^{21}$ Common themes include virulent anti-migrant stances; sometimes racist, sexist, and homophobic themes; and asserted crises that have the legal effect, if not the intent, of giving those political leaders exceptional powers - several of those themes are discussed in this article. When these narratives are given prominence, they take a great deal of room in political conversation, and they can distract from other agendas, or from other important events, or even simply serve to cloud an otherwise clear issue.

This article looks at these nationalistic narratives through the lens of recent events in the U.S. to argue that false anti-migrant political narratives can erode foundational legal norms if allowed to flourish. This link is somewhat recognized in countries such as Canada, where "hate speech" is criminalized because of the demonstrable harm to members of minority groups who might be targeted by such speech, and the Criminal Code provisions have been upheld under Canada's Charter of Rights and Freedoms freeexpression provision. ${ }^{22}$ The U.S does not have such a prohibition on hate speech, in large part because of its differing First Amendment tradition, nor is such a prohibition necessarily argued here. ${ }^{23}$ What is argued is that false political narratives must be at least critiqued in the legal field, because they cannot be disentangled from law, and the impact of current nationalistic narratives on legal norms could be devastating. Examples of this abound around the world, but the U.S. provides an accessible case study, in part because of the President's unprecedented ways of using his Twitter account to record real-time statements, as well as a recent appellate court ruling indicating that the President's Twitter contains official Government statements and that, thus, Trump's blocking of followers violates the First Amendment of the U.S. Constitution. ${ }^{24}$ Accompanied by a comparable decline in access by the media to

increased civilian deaths under the regime's policies, the Government has created a narrative presenting death as an ordinary part of life).

${ }^{21}$ For a diverse discussion of some examples see Rogers Brubaker, "Between Nationalism and Civilizationism: The European Populist Moment in Comparative Perspective" (2017) 40:8 Ethnic and Racial Studies 1191 (assessing a distinctive form of nationalism that has arisen in a specific part of Europe); Ramsey Dahab \& Marisa Omori, “Homegrown Foreigners: How Christian Nationalism and Nativist Attitudes Impact Muslim Civil Liberties" (2018) 42:10 Ethnic and Racial Studies 1727.

22 See generally $R v$ Keegstra, [1990] 3 SCR 697, [1991] 2 WWR 1 (SCC)(Canada)(explaining in detail the values supporting upholding the Canadian Criminal Code's "hate speech" provision); see also Criminal Code, RSC 1985, c C-46, s 319 (2); Canadian Charter of Rights and Freedoms, s 2(b), Part 1 of the Constitution Act, 1982, being Schedule B to the Canada Act 1982 (UK), 1982, c 11.

${ }^{23}$ See U.S. Const. amend I.

${ }^{24}$ One might also argue that the ability for Americans to directly comment on Trump's Twitter account represents an equally significant shift in the manner of presentation of a political narrative. 
the President for questions, this mechanism represents a shift in the way the U.S. Executive controls the political narrative and provides a ready vehicle for addressing this narrative issue. ${ }^{25}$

Section I argues that nationalistic narratives, focused on particular groups of migrants, have significantly emerged in a new and troubling way in a wide range of countries. The Section then focuses particularly on such narratives within the U.S., by arguing that the U.S. President is advancing false, racialized anti-migrant narratives on a major level, and that the claimed "crisis" of illegal immigration to the U.S. is not based on existing facts. Section II suggests that these false narratives have created a different kind of crisis - a "wag the dog" scenario, as seen in the plight of traumatized migrant children ripped from their families and migrants held in shocking detention conditions. The paper concludes by arguing that this continuum is not necessarily directly aimed at migration, but that anti-migration rhetoric is having the effect of giving increasing executive power to the President, while eroding constitutional individual due-process rights, as well as having devastating practical effects. ${ }^{26}$

See generally Tamara Keith, “Commander-In-Tweet: Trump's Social Media Use and Presidential Media Avoidance" NPR (18 November 2016), online: <https://www.npr.org/2016/11/18/502306687/commander-in-tweet-trumps-social-media-use-andpresidential-media-avoidance $>$ (providing an early commentary comparing Obama's public statements with Trump's shortly after winning the Presidential election and noting that Trump is more likely to turn to Twitter or messaging environments like carefully selected interviews, which he can control)[Keith]; Frank Newport, "Deconstructing Trump's Use of Twitter" Gallup (16 May 2018), online: <https://news.gallup.com/poll/234509/deconstructing-trump-twitter.aspx> (noting that Trump's "unprecedented" use of Twitter reaches a significant percentage of Americans, and that Trump himself has said, on Twitter, that he does it to get the "unfiltered message" out). For a scholarly assessment of Trump's use of Twitter see Michele Lockhart, ed, President Donald Trump and His Political Discourse: Ramifications of Rhetoric via Twitter (New York: Routledge 2019). For the appellate ruling on Trump's Twitter, see Knight First Amendment Institute at Columbia University et al $v$ Trump, No. 18-1691-cv (2nd Cir 2019).

${ }^{25}$ Keith, supra note 24 . Similarly, this piece cites extensively to media sources, in part because many of the events discussed are quite current and in part because media representations are central to the creation and perception of the political narratives discussed herein.

${ }^{26}$ See Anthony D. Romero, “Donald Trump: A One-Man Constitutional Crisis” ACLU (13 July 2016), online: <https://www.aclu.org/issues/executive-branch/donald-trump-one-man-constitutionalcrisis>. 


\section{SECTION I: NATIONALISTIC NARRATIVES AND FEAR OF “THE OTHER" ARE INCREASINGLY TRANSNATIONAL WITH A SPECIFIC RESURGENCE IN THE U.S.}

The study of political narratives has been the subject of extensive academic discussion, and certainly in recent years, in fields such as political science and sociology. ${ }^{27}$ Narratives have been studied as the vehicle affecting how people view the world. ${ }^{28}$ Much has thus been written about narratives and their impact on human perceptions. ${ }^{29}$ Narratives are recognized as an important tool in shaping "political identity, perspective, and ideology." 30 It is not necessary to assess academic literature to see that political speech is often framed in terms of narratives, as that is, in many ways, a matter of common sense. Much of the literature, though, provides a rich understanding of different forms, uses, and impacts of these types of narratives. ${ }^{31}$ That a narrative is presented or perceived in a certain way does not automatically suggest dishonest intent. But as Orwell so eloquently stated in the quote used above, politicians may well be aware of the power of advancing false narratives for nefarious reasons. ${ }^{32}$

Political narratives cannot always be disentangled from legal narratives, and it is apparent that the recent wave of nationalistic narratives is often being woven into the legal fabric of the national jurisdictions involved. Once embedded, it can be difficult to disentangle them. Flawed political narratives have a direct impact on developments in law, sometimes through specific problematic enactments, and, less often but more alarmingly, through systematic erosions of foundational constitutional principles. In my book, Detention of Terrorism Suspects: Political Discourse and Fragmented Practices, I wrote about erosions in constitutional detention, fair-trial, and interrogations standards, primarily emanating from post-September 11, 2001 (“9/11") U.S. political narratives, but impacting other jurisdictions, after the 9/11 terrorism attacks. ${ }^{33}$

This article represents a continued thread from that theme, and it argues that those types of flawed narratives, and resulting legal erosions, never stopped, but

27 See eg Saul R. Shernhev, "Political Narratives and Political Reality," (2006) 27:3 International Political Science Review 245.

${ }^{28} \mathrm{Ibid}$. at 246.

29 See generally ibid.

$30 \mathrm{Ibid}$. at 245.

${ }^{31}$ See ibid. for a discussion of the various threads of "narrative" academic literature.

32 See Orwell, supra note 15.

${ }^{33}$ Duffy, supra note 2 . The expansive themes in the book serve as a foundation for the arguments set forth herein. 
simply changed in form and expanded, and that foundational and long-standing constitutional principles are increasingly under threat as a result. As some men continue to languish indefinitely at Guantanamo Bay with little public outcry anymore, children are now being held in "cages" under horrific conditions at the U.S.-Mexico Border (alternatively referred to as "the Border"). ${ }^{34}$ There is outcry involving this now, as discussed at length below. But there is a question as to whether this, too, will become normalized over time, and whether these erosions are part of a continuum. ${ }^{35}$ Evidence of that type of threat to the Rule of Law is apparent in a rising number of national jurisdictions. ${ }^{36}$

Whatever the basis for these nationalistic sentiments, it is clear that they are fairly widespread in this political moment. They are often accompanied by extreme rightwing agendas and seizure of exceptional power by those political leaders advancing these narratives, portraying migrants in dehumanizing terms, suggesting that they are dangerous for whatever reason. For instance, Poland's Jaroslaw Kaczynski said migrants have brought diseases like cholera and dysentery to Europe and "all sorts of parasites and protozoa, which ... while not dangerous in the organisms of these people, could be dangerous here." 37 Hungary's PM, Viktor Orban, said "[w]e don't see these people as Muslim refugees. We see them as Muslim invaders." ${ }^{38}$ Italy's Matteo Salvini embraced the slogan "Italians First." 39 In Brazil, Jair Bolsonaro said "[t]he scum of the earth is showing up in Brazil, as if we didn't have enough problems of our own to sort out." 40

34 See the discussion of this issue and accompanying notes in Section II below.

35 See Duffy, supra note 2, where I discussed the ways in which altered detention practices for terrorism suspects normalized over time.

36 This has been extensively discussed. See eg George Monbiot, "From Trump to Johnson, Nationalists Are on the Rise - Backed by Billionaire Oligarchs" The Guardian (26 July 2019), online: <https://www.theguardian.com/commentisfree/2019/jul/26/trump-johnson-nationalists-billionaireoligarchs $>$.

37 Reuters, "Polish Opposition Warns Refugees Could Spread Infectious Diseases" Reuters (15 October 2015), online: <https://www.reuters.com/article/us-europe-migrants-poland/polish-oppositionwarns-refugees-could-spread-infectious-diseases-idUSKCN0S918B20151015>.

38 Orla Barry, “In Orbán's Hungary, Refugees Are Unwelcome - So Are Those Who Try to Help" PRI's the World (11 February 2019), online: <https://www.pri.org/stories/2019-02-11/orban-s-hungaryrefugees-are-unwelcome-so-are-those-who-try-help>.

39 Julia Khrebtan-Hörhager, "Italians First: The New Borders of European Humanity" Europe Now Journal (4 February 2019), online: <https://www.europenowjournal.org/2019/02/04/italians-first-thenew-borders-of-european-humanity/>.

40 Guardian Staff, "Who is Jair Bonsonaro? Brazil's Far-Right President in his Own Words" The Guardian (29 October 2019), online: <https://www.theguardian.com/world/2018/sep/06/jairbolsonaro-brazil-tropical-trump-who-hankers-for-days-of-dictatorship $>$. 
Turning back to the U.S., it cannot be disputed that there are serious humanrights concerns at the U.S.-Mexico Border, as discussed in more detail in Section II. According to the Border Network for Human Rights, which documents conditions for migrants at the Border:

In 2016, with the election of the Trump Administration, everything changed. Previously decreasing patterns of abuse started to shoot upward. Agencies that had changed their ways started to aggressively intrude on people's dignity and rights. And what we have seen in this year's report is unprecedented. The number of abuses and the degree of seriousness of those abuses is something we have not seen in our twenty years working with borderland communities. The state of human rights in the U.S.Mexico borderlands is grave, and is only getting worse. ${ }^{41}$

This deteriorating situation did not occur overnight, and it is also not entirely new. The U.S. has a long-term history of actions at the U.S.-Mexico Border with an obvious racial motivation. ${ }^{42}$ U.S. Representative Ilhan Omar recently suggested that this Administration's more openly hostile narrative is actually a good thing, because past administrations were able to conceal similar acts under a more polished political narrative. Pointing to Obama's policies of also "caging" unaccompanied minors and his highly controversial drone attacks, she said:

We can't be only upset with Trump. ... His policies are bad, but many of the people who came before him also had really bad policies. They just were more polished than he was ... And that's not what we should be looking for anymore. We don't want anybody to get away

\footnotetext{
${ }^{41}$ Border Network for Human Rights, "The State of Human Rights at the U.S.-Mexico Border" BNHR (June 2019), online: <http://bnhr.org/wp-content/uploads/2019/06/BNHR-Abuse-DocumentationCampaing-Report-2019-.pdf>.

42 See Kelly Lytle Hernandez, "How Crossing the US-Mexico Border Became a Crime" The Conversation (30 April 2017) online: <https://theconversation.com/how-crossing-the-us-mexicoborder-became-a-crime-74604>; Kelly Lytle Hernandez, City of Inmates: Conquest, Rebellion, and the Rise of Human Caging in Los Angeles, 1771-1965 (UNC Press 2017)(providing more history on the U.S.Mexico Border and the move to limit crossings).
} 
with murder because they are polished. We want to recognize the actual policies that are behind the pretty face and the smile. ${ }^{43}$

The narratives, though, are a form of harm in their own right, and prior problematic policies may have emboldened the U.S. to enhance its negative commentary. The current, openly hostile narratives about migrants are possibly allowing for a comparable escalation in abusive governmental action or serve as an indicator that things are getting much worse.

A narrative, of course, can have a counter-narrative. Trump's Twitter posts against U.S. Representative Elijah Cummings provide an example. Cummings has been extremely outspoken in condemning Trump's policies, particularly at the U.S.Mexico Border. ${ }^{44}$ In July 2019, Trump criticized Cummings, writing, among other things: “...As proven last week during a Congressional tour, the Border is clean, efficient \& well run, just very crowded. Cumming District is a disgusting, rat and rodent infested mess. If he spent more time in Baltimore, maybe he could help clean up this very dangerous \& filthy place". ${ }^{45}$ Trump's posts were widely criticized, with the Speaker of the U.S. House of Representatives openly calling them "racist." 46 In its Sunday editorial, the Baltimore Sun lambasted Trump for his comments, saying, among other things:

It's not hard to see what's going on here. The congressman has been a thorn in this president's side, and Mr. Trump sees attacking African American members of Congress as good politics, as it both warms the cockles of the white supremacists who love him and causes so many of the thoughtful people who don't to scream. President Trump badmouthed Baltimore in order to make a point that the border camps are "clean, efficient \& well run," which, of course, they are not unless you are fine with all the overcrowding, squalor, cages and

43 Tim Alberta, “The Democrats' Dilemma" Politico (8 March 2019), online: $<$ https://www.politico.com/magazine/story/2019/03/08/ilhan-omar-dean-phillips-minnesotademocratic-party-225696>.

44 "Trump Says Cummings Lied About Conditions in Migrant Detention Facilities. Did He?" PBS News Hour (29 July 2019), online: https://www.pbs.org/newshour/show/trump-says-cummings-lied-aboutconditions-in-migrant-detention-facilities-did-he>.

45 Donald J. Trump, Twitter (27 July 2019), online: $<$ https://twitter.com/realDonaldTrump/status/1155073965880172544> (errors in original).

46 Nancy Pelosi, Twitter (29 July 2019), online: $<$ https://twitter.com/SpeakerPelosi/status/1155148508296613889>. 
deprivation to be found in what the Department of Homeland Security's own inspector-general recently called "a ticking time bomb." ${ }^{47}$

While the Sun's editorial board did not evoke the "wag the dog" expression, that is what they were suggesting, that Trump was undertaking racist attacks on members of Congress to advance his own false narrative about conditions for detainees at the U.S.-Mexico Border, as well as simply to distract from the controversy. Clearly angered that Trump included derogatory comments about Baltimore in his post, the editors could not resist flipping Trump's "rat" narrative on him, as shown through the title of the piece, "Better to have a few rats than to be one." 48

\section{Why Anti-Migrant Narratives Now?}

Counter-narratives may not be enough to refute a false political narrative. In recent years, the global refugee crisis that arose, in part, from the conflict in Syria, had fueled anti-migrant narratives. ${ }^{49}$ Anti-migrant or other racialized narratives have appeal for politicians and others looking for scapegoats. As Payam Akhavan recently said:

By assigning blame to someone else, we absolve ourselves of responsibility; we avoid having to confront our fears and failures. Scapegoating is essentially dehumanization. We cannot hate and harm others if we see in them a shared humanity, a reflection of our own self. That is also why radical evil is typically justified in the

\footnotetext{
${ }^{47}$ Baltimore Sun Editorial Board, "Better to Have a Few Rats Than to be One" Baltimore Sun (28 July 2019), <https://www.baltimoresun.com/opinion/editorial/bs-ed-0728-trump-baltimore-20190727k6ac4yvnpvcczlaexdfglifada-story.html> [Baltimore Sun Editorial].

48 Ibid.

49 See United Nations Office for the Coordination of Humanitarian Affairs, "About OCHA Syria," UNOCHA, online: <https://www.unocha.org/syrian-arab-republic/about-ocha-syria> (detailing the still dire situation for civilians in Syria); UN Refugee Agency, "Syria Emergency," United Nations, online: <https://www.unhcr.org/syria-emergency.html > (saying that 5.6 million Syrians have fled the country since 2011, with another approximately 6.6 million displaced within Syria, from a pre-war population of approximately 22 million. Many more, not displaced, are in dire need of humanitarian assistance).
} 
name of a greater good, glorified as purification and cleansing, or as self-defence against foreign invasion or sinister conspiracies. ${ }^{50}$

Migrants are particularly vulnerable, seen as outsiders by some, and without many of the rights granted to citizens. If those narratives can also be infused with racialized slurs, the sad reality is that they can stir up a particular base that is predisposed to such messaging. Political actors may also exploit such sentiments to accomplish another end, such as distracting from other problems, or to allow them to stir up a base simply to expand their power. ${ }^{51}$ Such flames can be fanned intentionally. Akhavan, who was a prosecutor at the International Criminal Tribunal for the former Yugoslavia, observes that:

amidst the turbulence of the post-communist transition, ethnic entrepreneurs fanned the flames of fear against Bosnian Muslims, invoking the history of Ottoman wars from 600 years ago to warn against an imminent Turkish invasion. It was said that the ethnic war was not the result of spontaneous combustion; it was the work of pyromaniacs ... the narrative of hatred is always the same. The dehumanization of others is always a prerequisite for their destruction." 52

He adds that the Holocaust began "with words," and that, "[s]ocial media has multiplied these megaphones, and given once marginal elements a disproportionate voice." 53

It is easier to dehumanize people if there are obvious external differences. Different ways of dressing, different customs, visible difference in race, a sense of being unwilling to "assimilate," differences in language - all of these "differences," rather than being embraced as adding to a multicultural community, can be used to stir negative anti-migrant, or generally racist, sentiments. In his recent memoir, Trevor Noah speaks of his childhood under Apartheid in South Africa, as a child of "mixed" race. He tells a story about a group of teenagers, who were discussing amongst themselves a plan to mug him. They did not realize he could speak their language, because people who looked like him typically would not be able to. He

50 Payam Akhavan, "Finding Empathy in the Age of Rage" Open Canada (22 May 2019) $<$ https://www.opencanada.org/features/finding-empathy-age-rage/> [Akhavan].

${ }^{51}$ Ibid.

52 Ibid.

${ }^{53}$ Ibid. 
spoke to them in their language, offering to join them in their activities, and their demeanour towards him completely changed once they realized he spoke their language and was, thus, one of them. This and several other incidents "made [him] realize that language, even more than color, can define who you are to people." 54 In response, he became what he described as a "chameleon" speaking to people in their own languages and otherwise convincing them that he was one of them, not the Other, and it dramatically changed how people related to him..$^{55}$

Individual racism is obviously problematic. Systematic appeal to racism in the political sphere is very different and more dangerous. Akhavan points out " $[t]$ here is a vast difference between deviant violence on the social periphery and the mainstream legitimization of extremism as a means of acquiring power. Therein lies the difference between random hate crimes at one end of the spectrum and genocidal violence at the other end." 56

Anti-migrant narratives are transcending national boundaries, particularly so now, even while such narratives, by definition, involve a turning inward, a closing of doors, within a national jurisdiction. Where those narratives exist, violence may follow. Akhavan describes it as:

We live in what Pankaj Mishra calls the "age of anger," gripped by a "global pandemic of rage." Human rights advocates despair as demagogues [skillfully] exploit a pervasive and increasingly violent collective narcissism to gain power. We now talk openly about the emergence of fascism; we are no longer surprised by racist mass killings. We witness an unprecedented assault on long-cherished democratic ideals and institutions, a retreat from multilateralism, unravelling the liberal global order we once took for granted. Thrust into profound uncertainty and anxiety, we desperately cling to an increasingly romanticized past; we fantasize about going back to a better future, making liberalism great again. Yet, it is in that same imagined past that we find the historical currents that have brought us to this turbulent juncture. ${ }^{57}$

Maria Henein similarly suggested in a recent talk about the Rule of Law that the motivation behind current anti-migrant narratives may have nothing to do with migrants, but is more about "[d]eligitimizing the legal system and consolidation of

54 Trevor Noah, Born a Crime (Canada: Penguin/Random House/Doubleday Canada 2016) at 130.

55 Ibid.

${ }^{56}$ Akhavan, supra n 50.

${ }^{57}$ Ibid. 
power. That's what it's about. All under the guise that this one elected official is the true voice of the people. That's a scam friends. A complete and utter scam. Snake oil." 58 Significant research into this type of link is being done in other contexts, and in other jurisdictions, such as through the "Democratic Decay" initiative undertaken by a group of scholars to explore the perception that Democracy is being undermined on a global basis, hand-in-hand with these types of political narratives..$^{59}$

\section{RaCialized NARRATIVES, Especially Focusing ON Migrants, HAVE FANNED THE FlaMES OF NATIONALISM IN THE U.S.}

All nationalistic narratives are not the same, nor are the results of those narratives the same. It is impossible to include all of the racialized anti-migrant statements made during the Trump presidency, but some examples include when he complained about immigrants coming from "shithole countries," suggesting that it would be better to have immigrants from Norway. The New York Times reported Trump as saying that people coming from Haiti have AIDS, and that immigrants from Nigeria would never "go back to their huts." The White House later denied that he made any of these statements, allegedly during a private meeting. ${ }^{60}$

Certain threads demonstrate the tenor of comments by U.S. officials. The wellknown battle over what has been called the "Muslim Ban" demonstrates one thread, in which the U.S. Government has attempted to meet presidential campaign promises to block people from Muslim regions from entering the country, "until we figure out what is going on." ${ }^{61}$ One court included Trump's own statements regarding non-citizen Muslims to conclude that the intention was discriminatory and to temporarily block implementation of the ban. ${ }^{62}$

${ }^{58}$ Maria Henein, "Rule of Law" Ideacity 2019, online: <https://ideacity.ca/video/marie-henein-rule-oflaw/> (video) at 9:10-9:31.

59 "Democratic Decay \& Renewal: Bringing Democracy Defenders Together," online: $<$ https://www.democratic-decay.org/>.

${ }^{60}$ See Maureen Duffy, "'A Complete Corruption in Morality': U.S. Family Separation and the CanadaU.S. Safe Third Country Agreement" JURIST (17 July 2018), online: $<$ https://www.jurist.org/commentary/2018/07/maureen-duffy-corrupt-morality/> [Duffy: Family Separation] (many of the facts in this section are those that I included in a commentary I wrote about the "family-separation" policy. I cite that piece, omitting the internal citations, which can be found there).

${ }^{61}$ See Duffy, supra note 2 at 6-7, 9-10, 24-25, 162-163 (for a more detailed discussion of the legal controversy behind the so-called "Muslim Ban." Internal citations omitted here.).

62 International Refugee Assistance Project v Trump, No. 17-1351, 857 F.3d 554 (4 $4^{\text {th }}$ Cir 2017) at 573-574. 
Legal battles ensued, underscored by the insinuation from the U.S. Government that those seeking to enter the U.S., who were nationals of largely Muslim countries, were potential terrorists. ${ }^{63}$ After a series of lower-court rulings, requiring the U.S. Government to modify the travel ban, a version that was not limited solely to nationals of predominantly Muslim countries, although most of those affected were still from those countries, was upheld by the U.S. Supreme Court. ${ }^{64}$ The Court upheld the ban in the latest form, because it had been broadened beyond just predominantly Muslim countries, and because the President has extensive discretion under U.S. immigration law. ${ }^{65}$

As part of these initiatives, the Government specifically moved to stop Syrian refugees from entering the country. During a Presidential debate, Trump called permitting Syrian refugees into the country the "great Trojan horse of all time."66 Later, he said, "[i]f you're from Syria and you're a Christian, you cannot come into this country, and they're the ones that are being decimated. If you are Islamic ... it's hard to believe, you can come in so easily." 67 The truth of this statement about who is permitted into the U.S. has been called into question. ${ }^{68}$

The series of executive orders that have come to be known as the "Muslim Ban" are not unprecedented, and the final version bears some resemblance to President Bush's immigration initiatives after 9/11.69 A major difference, though, can be found in the political narratives advanced by both Presidents. After 9/11, Bush made a point of cautioning against painting all Muslims as terrorists, such as in his famous speech

63 See Duffy, supra note 2 at 6-7, 9-10, 24-25, 162-163 (internal citations included therein, giving much greater detail on this dispute).

${ }^{64}$ Trump v Hawaii, No 17-965, 585 U.S. _ (2018).

65 Ibid; see also Duffy, supra note 2 at 6-7, 9-10, 24-25, 162-163.

66 "Donald Trump Calls Syrian Refugees 'The Great Trojan Horse Of All Time'" Huffington Post $<$ https://www.huffingtonpost.ca/entry/donald-trump-calls-syrian-refugees-the-great-trojan-horse-ofall-time_n_5b507acbe4b00e8c8eb7259b> (video of Trump making the statement during a debate with Hillary Clinton).

${ }^{67}$ Louis Jacobson, “Donald Trump Says If You're from Syria and a Christian, You Can't Come to the U.S. as a Refugee" (20 July 2015) Politifact, online: <https://www.politifact.com/truth-ometer/statements/2015/jul/20/donald-trump/donald-trump-says-if-youre-syria-and-christianyou-/> (quotes the statement as a concern raised by Trump, but links to a video that has been deleted).

68 See ibid.

69 See United States Department of Justice, The September 11 Detainees: A Review of the Treatment of Aliens Held on Immigration Charges in Connection with the Investigation of the September 11 Attacks (June 2003) c. 4, U.S. Department of Justice, Office of the Inspector General; Maureen T. Duffy, The U.S. Immigration Detentions in the War on Terror: Impact on the Rule of Law (unpublished Master's thesis, McGill University, 2005)(focusing on the "special-interest" detainees in the U.S. after the 9/11 attacks). 
nine days after the attacks. He said "[t]he terrorists practice a fringe form of Islamic extremism that has been rejected by Muslim scholars and the vast majority of Muslim clerics; a fringe movement that perverts the peaceful teachings of Islam."70 He urged Americans not to lash out at innocent Muslims, saying "[ $t$ ]he enemy of America is not our many Muslim friends. It is not our many Arab friends. Our enemy is a radical network of terrorists and every government that supports them." 71

By contrast, Trump has made repeated, expressly anti-Muslim comments for years. For instance, when a Fox News interviewer once asked Trump if there was a "Muslim problem" he replied: “Absolutely. I mean, I don't notice Swedish people knocking down the World Trade Center. There is a Muslim problem in the world, and you know it and I know it."72 At another point, he said "I think Islam hates us."73

Narratives can sometimes be communicated by not communicating when one is expected to. When the "Unite the Right" group marched in 2017, some chanting Nazi-era slogans and carrying Nazi symbols, Trump initially declined to condemn them, instead condemning hatred "on many sides."74 Violent clashes emerged between protestors and counter-protestors, and one white supremacist intentionally drove his car into a crowd of counter-protestors, killing Heather Heyer and injuring others, some seriously. ${ }^{75}$ Trump received considerable negative attention when he

70 President George W. Bush, "Address to a Joint Session of Congress and the American People" The White House (20 September 2001), online: $<$ https://georgewbushwhitehouse.archives.gov/news/releases/2001/09/20010920-8.html>.

${ }^{71}$ Ibid.

72 Fox News, "Donald Trump Sits Down With Bill O'Reilly" The O'Reilly Factor (30 March 2011) $<$ https://www.foxnews.com/transcript/donald-trump-sits-down-with-bill-oreilly> (the statement is widely available in video form, but this citation is to the original source of the interview).

${ }_{73}$ Anderson Cooper, Interview, "Donald Trump: 'I Think Islam Hates Us' YouTube: CNN (9 March 2016), online: <https://www.youtube.com/watch?v=C-Zj0tfZY6o> (video of the interview and statement).

${ }^{74}$ Ayesha Rascoe, "A Year After Charlottesville, Not Much Has Changed For Trump" NPR (11 August 2018), online: <https://www.npr.org/2018/08/11/637665414/a-year-after-charlottesville-not-much-haschanged-for-trump $>$.

75 Paul Duggan \& Justin Jouvenal, “Neo-Nazi Sympathizer Pleads Guilty to Federal Hate Crimes for Plowing Car into Crowd of Protesters at 'Unite the Right' rally in Charlottesville" Washington Post (1 April 2019), online: <https://www.washingtonpost.com/local/public-safety/neo-nazi-sympathizerpleads-guilty-to-federal-hate-crimes-for-plowing-car-into-crowd-of-protesters-at-unite-the-rightrally-in-charlottesville/2019/03/27/2b947c32-50ab-11e9-8d28-

f5149e5a2fda_story.html?utm_term $=.8 \mathrm{f} 62805 \mathrm{e} 362 \mathrm{a}>$. 
suggested that there were "very fine people on both sides."76 It took strong political pressure for Trump to condemn the white nationalists, but he continued to suggest that the protestors more generally were not all white nationalists, saying that there were people there who were not involved with that, who were just protesting the removal of the statue from the Confederate Era. ${ }^{77}$

Trump's condemnation when perpetrators of violence are found to have been white nationalists has continued to be muted in terms of condemning the ideology. In early 2019, a gunman killed and injured people at a Mosque in New Zealand. It was later revealed that the gunman had a manifesto, containing white nationalist and anti-immigrant sayings and calling Trump "a symbol of renewed white identity."78 When asked, Trump said that he did not think white nationalistic violence was a growing threat, although he did criticize those espousing it. ${ }^{79}$ After he was told what the gunman had said about him, Trump said "I didn't see it. I didn't see it," he said. "But I think it's a horrible event ... a horrible, disgraceful thing and a horrible act." 80

Trump has, however, openly embraced the word "nationalist" in describing his "Make America Great Again" agenda. During a rally in October 2018, he said, "you know, they have a word - it's sort of became old-fashioned - it's called a 'nationalist.' And I say, really, we're not supposed to use that word. You know what I am? I'm a nationalist, okay? I'm a nationalist. Nationalist. Nothing wrong. Use that word. Use that word." ${ }^{\prime 1}$

The most focused aspects of recent U.S. anti-migrant narratives have possibly been reserved for people attempting to enter the U.S. through its Border with

${ }^{76}$ Glenn Thrush \& Maggie Haberman "Trump Gives White Supremacists an Unequivocal Boost" The New York Times (15 August 2017), online: <https://www.nytimes.com/2017/08/15/us/politics/trumpcharlottesville-white-nationalists.html?mcubz=0>.

77 Politico Staff, "Full Text: Trump's Comments on White Supremacists, 'Alt-Left' in Charlottesville" Politico (15 August 2017), online: <https://www.politico.com/story/2017/08/15/full-text-trumpcomments-white-supremacists-alt-left-transcript-241662> (saying "I'm not talking about the neoNazis and the white nationalists, because they should be condemned totally - but you had many people in that group other than neo-Nazis and white nationalists.").

78 Associated Press, "Trump Downplays Threat of White Nationalism Following New Zealand Massacre" CBC (15 March 2019), online: <https://www.cbc.ca/news/world/trump-new-zealandwhite-identity-1.5059127> [AP: New Zealand].

79 "Trump Says He Doesn't See White Nationalism as a Rising Global Threat After New Zealand Shooting" Time (15 March 2019), online: <https://time.com/5552850/donald-trump-whitenationalism-global-threat-new-zealand/>.

${ }^{80}$ AP: New Zealand, supra note 78.

${ }^{81}$ Jesse Ferreras, “Donald Trump: 'I'm a nationalist, OK? Nationalist. Use That Word, Use That Word'" Global News (22 October 2018), online: <https://globalnews.ca/news/4584546/donald-trumpnationalist-rally-texas/>. 
Mexico. Trump had campaigned on his promise to build a "wall" along the extensive Border, and he has invoked extraordinary powers to try to make it happen. He allowed the federal government to be shut down when the Democrat-controlled House of Representatives refused to agree to a budget that included funding for the wall. ${ }^{82}$ When he signed funding legislation to re-open the Government, without getting his wall funding, he declared a State of Emergency within a couple of weeks to allow him to redirect funding designated elsewhere for the wall. ${ }^{83}$

In 2019, a federal judge issued a temporary injunction against the Government's planned diversion of funds for the wall, which became a permanent injunction, writing:

Congress's 'absolute' control over federal expenditures-even when that control may frustrate the desires of the Executive Branch regarding initiatives it views as important-is not a bug in our constitutional system. It is a feature of that system, and an essential one ... In short, the position that when Congress declines the Executive's request to appropriate funds, the Executive nonetheless may simply find a way to spend those funds "without Congress" does not square with fundamental separation of powers principles dating back to the earliest days of our Republic. ${ }^{84}$

The ruling was upheld on appeal, but, in July 2019, the Supreme Court of the United States entered a stay on the lower court's injunction, thus freeing the Government to begin spending the money on the Wall while the litigation continues. ${ }^{85}$ Trump posted on his Twitter account: "Wow! Big VICTORY on the Wall. The United States Supreme Court overturns lower court injunction, allows Southern Border Wall to proceed. Big WIN for Border Security and the Rule of Law!" 86 He also

82 Steve Holland \& Richard Cowan, "Backing down, Trump agrees to end shutdown without border wall money" Reuters (25 January 2019), online: <https:/www.reuters.com/article/us-usashutdown/backing-down-trump-agrees-to-end-shutdown-without-border-wall-moneyidUSKCN1PJ126>.

${ }^{83}$ United States Federal Register, “Declaring a National Emergency Concerning the Southern Border of the United States," Proclamation 9844 National Archives (15 February 2019), online: <https://www.federalregister.gov/documents/2019/02/20/2019-03011/declaring-a-nationalemergency-concerning-the-southern-border-of-the-united-states>.

84 Sierra Club v Trump, Case No. 19-cv-00892-HSG (ND Cali 2019) at 54.

85 Trump v Sierra Club, 588 U. S. ___ (2019)(the Court gave only very brief reasons for its order).

86 Donald J. Trump, Twitter (26 July 2019), online: <https://witter.com/realDonaldTrump/status/1154883345546928128>. 
Tweeted: "Democrats don't care about Border Security. They refuse to give the votes necessary to fix the Loopholes and Asylum. Would be so easy! They want Open Borders, which means CRIME,CRIME,CRIME!" 87

This theme, equating migrants with criminals, is a thread that has woven through Trump's narratives for some time. A few other examples indicate the tone of the commentary. During his campaign for President, Trump told a crowd: "[w]hen Mexico sends its people, they're not sending their best; they're not sending you ... They're sending people that have lots of problems, and they're bringing those problems with us. They're bringing drugs. They're bringing crime. They're rapists. And some, I assume, are good people." 88 During one of the presidential debates, Trump said "we have some bad hombres here, and we're gonna get them out." 89 The narratives are far from subtle.

\section{SeCtion II: FAlSE RACIAlized AND ANTI-Migrant NARRATIVES HaVe Led to a TRUe Human-Rights CRISIS AT THE U.S.- MEXICO BORDER}

Perhaps the most disturbing outcome of these anti-migrant narratives relates to the "family separation" policy, dubbed the "Zero Tolerance Policy" by the U.S. Government. This is not the only controversial migration policy, as discussed above, but this one stands out for its sheer cruelty. Beginning in mid-2018, it was reported that the U.S. Government was separating children from migrant families at the Border, and stories emerged of the children being held in horrific conditions. ${ }^{90}$ When a court ordered the Government to return the children within a set timeframe, the Government admitted that some of the children had been lost and might never be reunited. ${ }^{91}$ The motivation for this policy was the Government's ongoing claim that there was a crisis of illegal immigration, which is not supported by the evidence. In responding to a "wag the dog" crisis, the U.S. created an actual human-rights crisis.

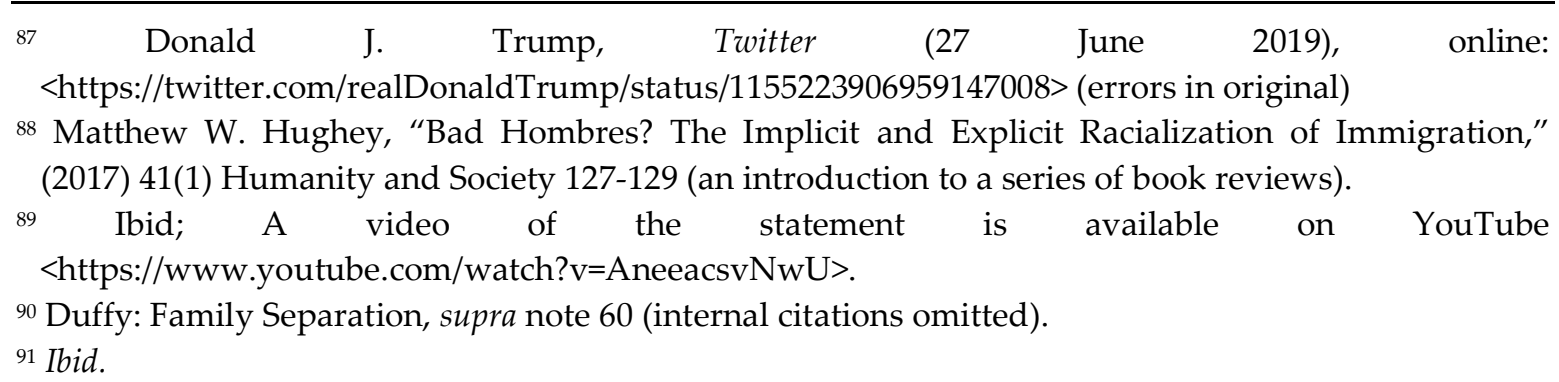




\section{A Fabricated Crisis Narrative at the U.S.-Mexico Border}

In addition to the relentless suggestion that those seeking to cross from Mexico are criminals, Government rhetoric has superimposed a constant narrative of crisis to support its actions. The Declaration of Emergency, described above, is an obvious example. Prior to the midterm elections in 2018, Trump made much of the "invasion" of a caravan of migrants heading north through Mexico." ${ }^{\prime 2}$ At one point, he wrote on Twitter: "Many Gang Members and some very bad people are mixed into the Caravan heading to our Southern Border. Please go back, you will not be admitted into the United States unless you go through the legal process. This is an invasion of our Country and our Military is waiting for you." 93

Trump regularly refers to migrants collectively as "illegals," without regard to their actual immigration status, using a word that is by definition dehumanizing. At one point, he posted on Twitter: "Mexico must use its very strong immigration laws to stop the many thousands of people trying to get into the USA. Our detention areas are maxed out \& we will take no more illegals. Next step is to close the Border! This will also help us with stopping the Drug flow from Mexico!"94

In mid-2019, the U.S. threatened trade sanctions against Mexico if it did not address the alleged crisis of migration, later backing away from what, itself, could have created an economic crisis. One commentator noted, in response to that scenario: “[o]ne of Donald Trump's signature moves as president is to act as both arsonist and firefighter, taking credit for resolving pseudo-crises that he in fact initiated."95 In July 2019, the U.S. threatened trade sanctions against Guatemala if it did not agree to be designated as a "safe third country," meaning that migrants passing through Guatemala would be required to seek asylum there and would thus be barred from seeking it in the U.S. This was a cynical move, since many recent asylum seekers at the U.S.-Mexico Border have actually come from Guatemala. ${ }^{96}$ The

\footnotetext{
92 See eg Donald J. Trump, Twitter (25 October 2018), online: $<$ https://twitter.com/realDonaldTrump/status/1055527191235227648>.

93 Donald J. Trump, Twitter (29 October 2018), online: <https://twitter.com/realDonaldTrump/status/1056919064906469376>.

94 Donald J. Trump, Twitter (30 March 2019), online: <https://twitter.com/realDonaldTrump/status/1112091249153134598 >.

95 Brendan Nyhan, "Trump Is Taking Credit for Resolving the Crises He Created" Medium (4 June 2019), online: <https://gen.medium.com/trump-is-taking-credit-for-resolving-the-crises-he-created35e4d720ed04>.

96 See Lauren Carasik, "Trump's Safe Third Country Agreement With Guatemala Is a Lie" Foreign Policy (30 July 2019) online: <https://foreignpolicy.com/2019/07/30/trumps-safe-third-countryagreement-with-guatemala-is-a-lie/>.
} 
Constitutional Court of Guatemala blocked the planned agreement, saying the President needed approval from Congress. Trump then threatened tariffs and other sanctions, including a tax on remittances sent back to Guatemala. Ultimately, a revised agreement was signed between the two countries. ${ }^{97}$

In spite of the constant suggestions that there is an "invasion" or an emergency at the border with Mexico, some statistics suggest that the numbers of illegal crossings at the Border have declined. According to the Pew Research Center, the number of undocumented aliens living in the U.S. has dropped to 2004 levels. ${ }^{98}$ The concerns about the numbers of undocumented immigrants had been dropping for some time. ${ }^{99}$ Moreover, the Center suggests that 2/3 of undocumented immigrants in the U.S. have already lived there for over 10 years. ${ }^{100}$ Various statistics also suggest that the percentage of undocumented immigrants in the U.S. as compared to the larger population of documented immigrants and citizens, is quite small. ${ }^{101}$

Government figures also suggest that criminality among migrants to the U.S. has also dropped. U.S. Customs and Border Protection, for instance, publishes annual statistics relating to the discovery of a past criminal conviction among "aliens" crossing into the U.S. In fiscal year 2016, 12,842 such people were found. By fiscal year 2018, it was down to 6,698. Very few of those crimes involved violence, and many were convictions for illegal entry or re-entry. Only 367 of these "aliens" were

\footnotetext{
97 See "Guatemala Signs Migration Deal with US After Trump Threats" BBC (27 July 2019), online: $<$ https://www.bbc.com/news/world-latin-america-49134544>. At the time of finalization of this article, the details of the agreement were unclear, and it was also unclear whether the agreement was in violation of the Constitutional Court's ruling. Ibid. The Court's announcement, in Spanish, is available at Resolutions in Files 3829-2019, 3849-2019 and 3881-2019. "Third Safe Country", Expedientes Acumulados 3829-2019, 3849-2019 y 3881-2019, Corte de Constitucionalidad República de Guatemala, C.A. (15 July 2019), online: <https://cc.gob.gt/2019/07/15/resoluciones-en-expedientes-3829-2019-3849/> (translated via the website's translation tool). For Trump's Twitter statements preceding the agreement see Donald J. Trump, Twitter (23 July 2019), online: <https://witter.com/realDonaldTrump/status/1153641906699681795> (first of a thread); see also The White House, Twitter (26 July 2019), online: <https://witter.com/WhiteHouse/status/1154861528539160576> (announcing the signing of the deal with Guatemala).

98 Jens Manuel Krogstad et al, "5 Facts About Illegal Immigration in the U.S." Fact Tank: Pew Research Center (12 June 2019), online: <https://www.pewresearch.org/fact-tank/2019/06/12/5-facts-aboutillegal-immigration-in-the-u-s/>. [Pew: Five Facts].

99 Ana Gonzalez Barrera, “What we know about illegal immigration from Mexico" Fact Tank: Pew Research Center (28 June 2019), online: <https://www.pewresearch.org/fact-tank/2019/06/28/what-weknow-about-illegal-immigration-from-mexico/>.

100 Pew: Five Facts, supra note 98.

101 Ibid.
} 
found to have had a prior drug possession or trafficking offense by mid-2019, relevant in light of Trump's claim that many are drug dealers. The total with drugrelated convictions in the past was 871 in 2018, down from 1,797 in 2016. ${ }^{102}$ A study by the Cato Institute in Texas showed that crimes there by undocumented immigrants were significantly lower than the number of those committed by documented aliens and U.S. citizens. ${ }^{103}$ One study concluded that higher numbers of undocumented aliens in a given state was actually associated with a decrease in violent crimes. ${ }^{104}$

While the language of "crisis" and criminality does not appear to be supported by available statistics, this does not mean there is not a crisis involving migration. The language of "crisis" has been used by the United Nations and other organizations to describe the situation of refugees fleeing from or through parts of Central America. ${ }^{105}$ That, of course, is a very different picture from the narrative of the "illegal criminal" immigrant. There are, as well, legal differences in status between asylum seekers and those simply seeking to enter the country without documentation, which make the narrative look quite different. ${ }^{106}$

In making the case for his Border wall, Trump continued to beat the drum of a crisis of criminals pouring over the Border, saying "[o]ver the years, thousands of Americans have been brutally killed by those who illegally entered our country and

102 United States Customs and Border Protection, "Criminal Alien Statistics Fiscal Year 2019" U.S. Department of Homeland Security, online: <https://www.cbp.gov/newsroom/stats/cbp-enforcementstatistics/criminal-alien-statistics>; see also Catherine E. Shoichet, "What 7 Statistics Tell Us About Immigration and Crime CNN (8 January 2019), online: <https://www.cnn.com/2018/11/03/us/immigrants-crime-numbers/index.html> (containing different statistics than those cited above, but using different parameters and sources and suggesting that one statistic, from Immigration and Customs Enforcement (ICE) has been criticized as inflated.)[Shoichet].

103 Shoichet, supra note 102.

104 Michael T. Light \& Ty Miller, “Does Undocumented Immigration Increase Violent Crime?” (2018) 56:2 Criminology 370 at 370.

105 See eg Amnesty International, "Fleeing for Our Lives: Central American Migrant Crisis" Amnesty International, online: <https://www.amnestyusa.org/fleeing-for-our-lives-central-american-migrantcrisis/>; United Nations Refugee Agency, "Central America Refugee Crisis" United Nations High Commissioner for Refugees, online: <https://www.unrefugees.org/emergencies/central-america/>.

106 See International Rescue Committee, “Migrants, Asylum Seekers, Refugees and Immigrants: What's the Difference?" IRC (22 June 2018), online: <https://www.rescue.org/article/migrants-asylumseekers-refugees-and-immigrants-whats-difference> (for basic information on some distinctions. A fuller argument relating to the legal status of asylum seekers will be beyond the scope of this article) $[\mathrm{IRC}]$. 
thousands more lives will be lost if we don't act right now."107 In early November 2018, Trump suggested that agents should respond with bullets if migrants at the Border throw rocks at them, which Border Patrol said it would not do. ${ }^{108}$ Trump said "[c]onsider it a rifle. When they throw rocks like they did at the Mexico military police, consider it a rifle." The next day, Trump said that this just meant to arrest people not to shoot them. ${ }^{109}$ During this time period, Trump also sent troops to the U.S. Border. ${ }^{110}$ On New Year's Day 2019, the U.S. Government fired tear gas into Mexico at migrants who were trying to cross the Border. Government officials said they were targeting rock throwers, not the migrants, and that no children were affected. This was disputed by an Associated Press photographer, who saw several iterations of tear gas thrown at the migrants, affecting the migrants, including children. The photographer said he only saw people throwing rocks after the tear gas was thrown. ${ }^{111}$

\section{A Real, Government-Created Crisis at the U.S Border}

Escalating actions have been taken to accompany the Government's criminalmigrant emergency narrative. For the purpose of this article, the example of detention conditions and "family separation" will illustrate how significant the larger shift in this area is. It appears that the U.S.'s claim of a crisis or invasion at the Border with Mexico is unsupported by the facts, but that the Government's response to accompany, or more likely give credence to, its crisis narrative has created a different kind of crisis. While not speculating about the actual intention behind using this crisis language, it is notable that, in various instances of action supporting the antimigrant narratives, the Executive Branch has asserted extended powers, as described above with the "Muslim Ban," the Declaration of Emergency for Wall funding, and certainly in relation to other actions at the Border. There have been trends towards extending Executive power in the U.S. for many years, escalating after the 9/11

\footnotetext{
${ }^{107}$ Cheyenne Haslett, “Fact Check: Trump's Claims on Undocumented Immigrant Crime Rates. Here's What the Numbers Show" ABC News (15 January 2019), online: $<$ https://abcnews.go.com/Politics/fact-check-trumps-claims-illegal-immigrant-crimerates/story?id=60311860> (quoting a statement Trump made during a speech in New Orleans).

108 Bob Ortega, "Trump Said Military Should Shoot Rock-Throwing Migrants. Officials Disagree." CNN (2 November 2018), online: <https://www.cnn.com/2018/11/02/us/officials-dismiss-shootingrock-throwing-migrants-trump-invs/index.html>.

109 Ibid.

${ }^{110}$ Ibid.

111 Associated Press, “U.S. Fires Tear Gas Across Mexico Border to Stop Migrants" NBC News (1 January 2019), online: <https://www.nbcnews.com/storyline/immigration-border-crisis/u-s-fires-teargas-across-mexico-border-stop-migrants-n953641>.
} 
attacks, which have been argued to be in contravention of the constitutional "checks and balances" set across the three branches. ${ }^{112}$ Narratives can only do so much, and a Government wishing to advance a particular false narrative is likely to take actions in furtherance of those narratives, as explained in those other examples. In its "familyseparation" and detention policies, the Government's actions appear, themselves, to have created an actual humanitarian crisis.

While estimates vary, it has been suggested that the U.S. Government has removed thousands of migrant children from their families under this program. ${ }^{113}$ While narratives are important to perception, a single image can spark its own powerful narrative, and there were images that emerged in 2018 that caused shock, including pictures of groups of children in cages with foil sheets and children sleeping on floor mats. Within these cages, older children were caring for younger children, including changing the diapers of children they did not know, because there was nobody else doing it. Parents often did not understand what was happening as their children were removed. Some were told the children were just being taken for baths. One mother said she was told that her children were being taken for "the crime of crossing the Border." Reports emerged of breast-feeding infants being removed from mothers, with one mother handcuffed for resisting. While removal of children in this manner raises serious legal questions regarding the Government's conduct, regardless of the legal status of the families, it was further reported that no distinction was made between people attempting to enter the country illegally and those legally claiming refugee status. A reporter noted that some refugee seekers were separated from their children, criminally charged, and only then given the opportunity to make their refugee claims. ${ }^{114}$ At one point, it was reported that parents were being told they could see their children only if they signed documents agreeing to waive their right to an asylum hearing and to be immediately deported. ${ }^{115}$

112 This assertion was often made, for example, during the presidency of George W. Bush, who, after the 9/11 attacks, issued a number of significant Executive Orders. See Melissa K. Mathews, "Restoring the Imperial Presidency: An Examination of President Bush's New Emergency Powers," (2001-2002) 23 Hamline J. Pub. Law 325. For a detailed discussion of the history behind the constitutional Executive power, see Saikrishna Bangalore Prakash, "The Imbecilic Executive" (2013) 99 Va. L. Rev. 1361. For further discussion of trends toward greater executive power after 9/11, which have, thus far, spanned the presidencies of Bush, Obama, and Trump, see Duffy, supra 2.

113 See Duffy: Family Separation, supra note 60.

114 Ibid.

115 Tal Kopan et al, "Separated parents given option for voluntary deportation amid child reunification" CNN (24 June 2018), online: <https://www.cnn.com/2018/06/24/politics/familyreunification-deportation-orders/index.html>. 
Some children were ultimately returned, while others were not. For those children returned, there were obvious signs of trauma. One mother said that, when her toddler was returned to her after 85 days, he was dirty and full of lice, as if he had not been bathed the entire time. ${ }^{116}$ Another person described a three-year-old boy, who was waiting to be reunited with his family, as "just a shell of himself." A four-year-old girl from Guatemala, who had been cared for by other children in her cell, was so traumatized that she was not speaking and was "just curled up in a little ball." The American Academy of Pediatrics warned that the trauma of the separation could cause permanent damage. ${ }^{117}$

As this controversy erupted, the Government publicly mentioned plans to open tent cities for the children in the desert. In apparent response to the backlash, Trump Tweeted "[w]e cannot allow our country to be overrun by illegal immigrants as the Democrats tell their phony stories of sadness and grief."118 In response to questioning, Trump said: "We want a great country. We want a country with heart. But when people come up, they have to know they can't get in. Otherwise it's never going to stop." 119 He attempted to explain that separating children from parents was necessary, saying "[w]hen you prosecute the parents for coming in illegally, which should happen, you have to take the children away. Now, we don't have to prosecute them, but then we're not prosecuting them for coming in illegally. That's not good." 120 Under great public pressure, Trump signed an Executive Order, which was supposed to reverse the policy. ${ }^{121}$ In late July 2019, the ACLU told a U.S. federal court

\footnotetext{
116 Ibid (with internal citations indicating that this incident happened before the "Zero-Tolerance Policy" was publicly announced, raising questions as to how long these separations had been taking place). For current litigation relating to this policy, see Mrs. L v ICE, No 3:18-cv-00428-DMS-MDD (SD Cal pending). Legal filings in this ongoing class-action lawsuit can be found on the website of the American Civil Liberties Union, <https://www.aclu.org/cases/ms-1-v-ice> [Mrs. L].

117 American Academy of Pediatrics, "AAP Statement on Executive Order on Family Separation" American Academy of Pediatrics (20 June 2018), online: <https://www.aap.org/en-us/about-the-aap/aappress-room/Pages/AAP-Statement-on-Executive-Order-on-Family-Separation.aspx>.

118 Donald J. Trump, Twitter (22 June 2018), online: <https://witter.com/realDonaldTrump/status/1010156224749408258>.

119 Meg Wagner et al, “What's Happening at the U.S. Border" CNN (22 June 2018), online: $<$ https://www.cnn.com/politics/live-news/immigration-border-childrenseparation/h_5652f6b137eaba6711e304f376476c94>.

120 Ibid.

${ }^{121}$ See Executive Office of the President, "Affording Congress an Opportunity To Address Family Separation" Federal Register (25 June 2018), online: <https://www.federalregister.gov/documents/2018/06/25/2018-13696/affording-congress-anopportunity-to-address-family-separation>.
} 
that almost 1,000 child migrants had been removed from their families since the prior court order that the children be returned. ${ }^{122}$

In mid-2019, new reports emerged of migrants at the U.S.-Mexico Border being detained in appalling conditions. ${ }^{123}$ In June 2019, an attorney for the U.S. Government argued before a clearly incredulous panel of the United States Court of Appeals for the Ninth Circuit that the U.S. Government was not required to provide toothbrushes, soap, or warm places to sleep for thousands of migrant children it was detaining. ${ }^{124}$ Numerous organizations and media outlets have reported on deteriorating, crowded, and dangerous conditions for these detained migrants, all troubling, but that much more so when the detainees are children who were taken from their parents before being so detained. ${ }^{125}$ It was this controversy that led to Trump's "rat-infested" remarks about Rep. Cummings' district in Baltimore, discussed above.

The reports of conditions at these centres have been extensive. Seven children are reported to have died in U.S. custody or after having been detained. ${ }^{126}$ A reporter who visited a detention centre with Vice-President Mike Pence said the smell was unbearable, and that 400 men were in cages that were hot and so crowded they could

${ }_{122}$ Maria Sacchetti, “ACLU: U.S. Has Taken Nearly 1,000 Child Migrants from Their Parents Since Judge Ordered Stop to Border Separations" Washington Post (30 July 2019), online: $<$ https://www.washingtonpost.com/immigration/aclu-us-has-taken-nearly-1000-child-migrantsfrom-their-parents-since-judge-ordered-stop-to-border-separations/2019/07/30/bde452d8-b2d5-11e98949-5f36ff92706e_story.html?noredirect=on\&utm_term=.7f2d9db9036f $>\quad$ (the Government has asserted that it only removes children if they are at risk, and the ACLU is presently disputing that assertion).

${ }^{123}$ See eg James Sergent et al, "Chilling First-Hand Reports of Migrant Detention Centers Highlight Smell of 'Urine, Feces,' Overcrowded Conditions" USAToday (17 July 2019), online: $<$ https://www.usatoday.com/in-depth/news/politics/elections/2019/07/16/migrant-detention-centersdescribed-2019-us-government-accounts/1694638001/> (compiling first-hand statements from various people who had seen the centres) [Sergent].

124 See Flores v Barr, No 17-56297 YouTube: United States Court of Appeal for the Ninth Circuit (18 June 2019), online: <https://www.youtube.com/watch?v=Z2GkDz9yEJA\&t=2423s> (video of oral argument). The argument was a bit more nuanced than media reports suggested, as the lawyer was arguing about the interpretation of a prior agreement. The details of that agreement are beyond the scope of this article, but it is noted that this clarification does not make the Government's argument any less disturbing.

${ }^{125}$ See eg Sergent, supra note 123.

${ }^{126}$ Cynthia Pompa, “Immigrant Kids Keep Dying in CBP Detention Centers, and DHS Won't Take Accountability" ACLU (24 June 2019), online: <https://www.aclu.org/blog/immigrantsrights/immigrants-rights-and-detention/immigrant-kids-keep-dying-cbp-detention>. 
not possibly all lie down at one time. ${ }^{127}$ A guard at the facility admitted the men had not showered for 10-20 days. ${ }^{128}$ The Inspector General for the Department of Homeland Security quoted an employee of one of the centres as calling the situation a "ticking time bomb" because of the horrific conditions. ${ }^{129}$ While Trump has denied that the conditions in the centres are bad, photos contained within the Inspector General's report show cages packed with people, barely allowing room for movement. ${ }^{130}$ The crisis nature of the appalling conditions is reflected in the opening lines of the Inspector General's Report: "For your action is our final management alert, Management Alert - DHS Needs to Address Dangerous Overcrowding and Prolonged Detention of Children and Adults in the Rio Grande Valley, the purpose of which is to notify you of urgent issues that require immediate attention and action." 131 The report indicated that at least 50 children had been held for more than 72 hours with no access to showers, limited access to a change of clothes, and no access to hot meals. ${ }^{132}$ At another facility, "some single adults were held in standing room only conditions for a week and at another, some single adults were held more than a month in overcrowded cells." 133 Photos were included with a description suggesting that 52 adult women were being held in a cell designated for male minors, and with a capacity of 40 , and another photo showed 71 adult men held in a cell designated for 41 adult women. ${ }^{134}$ In the absence of showers for up to a month in some cases, some facilities were giving detainees wet wipes to use to clean themselves. ${ }^{135}$ A legal team visiting one centre found three girls trying to take care of a toddler after a guard brought him in and asked who wanted to care for him. He had "wet his pants and had no diaper and was wearing a mucus-smeared shirt"

\footnotetext{
127 Sergent, supra note 123.

128 Ibid.

129 Ibid; Office of Inspector General, "Management Alert -DHS Needs to Address Dangerous Overcrowding and Prolonged Detention of Children and Adults in the Rio Grande Valley (Redacted)" Department of Homeland Security (2019), online: <https://www.oig.dhs.gov/sites/default/files/assets/2019-07/OIG-19-51-Jul19_.pdf.> [OIG Report].

130 See Michael Collins \& David Jackson, “Trump Says Detention Facilities 'Beautifully Run' After Report Describes Dangerous Conditions" USA Today (5 July 2019), online: $<$ https://www.usatoday.com/story/news/politics/2019/07/05/immigration-trump-defends-beautifullyrun-detention-facilities/1660455001/> [Collins]; OIG Report, supra note 129.

${ }^{131}$ OIG Report, supra note 129.

132 Ibid at 6.

133 Ibid.

134 Ibid at 7.

135 Ibid at 8-9.
}

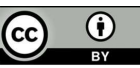


when the team saw him. ${ }^{136}$ In July, after the Inspector General's report was released, Trump said of the centres "I've seen some of those places, and they are run beautifully," he said. "They're clean. They're good. They do a great job."137

As widespread publicity focused on these centres, the importance of narratives was demonstrated through a continuing war of words. Representative Alexandria Ocasio-Cortez stirred controversy when she called the centres "concentration camps," which is recently an expression used most often in regard to Nazi death camps. ${ }^{138}$ When challenged, she held to the term, posting the definition and arguing that detentions under such conditions sink to that level, pointing out that her intentional use of the term started an important conversation about learning from history. ${ }^{139}$ At the same time, those supporting the Administration made a continued point of referring to the people detained as "illegals," clearly trying to mute opposition to the conditions by dehumanizing those detained. ${ }^{140}$ In 2018, it was reported that the Department of Justice had ordered its employees to use the term "illegal alien" instead of "undocumented immigrant."141 Trump said that separating families was a way to deter illegal immigration. "If they feel there will be separation, they don't come," he said. ${ }^{142}$ Then-Attorney General Jeff Sessions took the notion of "illegality" farther in earlier comments, suggesting that there was Biblical authority for the policy: "Persons who violate the law of our nation are subject to prosecution. I would cite you to the Apostle Paul and his clear and wise command in Romans 13 to

${ }^{136}$ Associated Press, “'Tragic Conditions': Migrant Kids at Texas Border Facility Neglected and Lack Food, Water and Sanitation" CBC (21 June 2019), online: <https://www.cbc.ca/news/world/texas-elpaso-migrant-children-neglect-1.5185329>.

${ }^{137}$ Collins, supra note 128.

138 Caroline Kelly, “Ocasio-Cortez on Calling Detention Centers 'Concentration Camps': We Have to 'Learn From Our History'” CNN (27 June 2019), online: $<$ https://www.cnn.com/2019/06/27/politics/alexandria-ocasio-cortez-concentration-camps-the-leadcnntv/index.html> (including a video interview with Ocasio-Cortez on the issue).

139 Ibid.

${ }^{140}$ Camila Ruiz, “The Battle Over the Words Used to Describe migrants” BBC (28 August 2015), online: <https://www.bbc.com/news/magazine-34061097> (noting there has been some criticism of the word "migrant" as well, since some people are refugees, which has a very different connotation; see also IRC, supra note 106

141 Ana Campoy, “US Officials Must Now Say 'Illegal Aliens,' Not 'Undocumented Immigrants'” QZ (25 July 2018), online: <https://qz.com/1336110/its-illegal-aliens-not-undocumented-immigrants-saysthe-us-department-of-justice/>.

142 David Shepardson, “Trump Says Family Separations Deter Illegal Immigration” Reuters (13 October 2018), online: <https://www.reuters.com/article/us-usa-immigration-trump/trump-says-familyseparations-deter-illegal-immigration-idUSKCN1MO00C>. 
obey the laws of the government because God has ordained them for the purpose of order." 143

Other examples served to suggest a dehumanizing response, such as when a senior official at ICE was asked during a Congressional hearing about a three-yearold girl who had been separated from her family for 47 days. When asked whether the child was a criminal or national security risk, he said he did not know. ${ }^{144}$ The official was also asked about the process for deporting parents after removal of children. He acknowledged that his department did the deportation. When asked if he deported people while the children were still separated, possibly in another city, he replied that they did not do reunification, acknowledging under further questioning that they did the deportations before reunification and without knowledge about reunification. Representative Jerry Nadler, who was questioning him, then said "[s]o, in other words, you're kidnapping the child." The officer replied, "[w]e're not kidnapping the child. We follow the guidelines that are out," to which Nadler replied "[d]eporting a parent without their child is literal kidnapping." 145 Information revealed from a Judiciary Committee investigation indicates that the Government intended for family separations to be permanent. ${ }^{146}$

\section{Conclusion: An Escalating “CRisis" But Not the One Claimed BY THE U.S. GOVERNMENT}

The situation playing out in the U.S. shows how quickly political narratives can have devastating practical and legal consequences. The stories of traumatized children ripped from their families, and of people being held in such horrific conditions, are appalling. Throughout this article, speculation has been included as to why anti-migrant narratives have become so widespread, with the most common theme being that these narratives can help political leaders to gather greater power. It is apparent that, as described throughout this article, Trump has used executive power in the U.S. in an expansive way, so far with some measure of success. Appeal to a particular base may be the political impact of such actions, but there are also

\footnotetext{
${ }^{143}$ Rev. Dr. Margaret Aymer \& Laura Nasrallah, "What Jeff Sessions Got Wrong When Quoting the Bible" Washington Post (15 June 2018), online: <https://www.washingtonpost.com/news/acts-offaith/wp/2018/06/15/what-jeff-sessions-got-wrong-when-quoting-thebible/?utm_term=.1927398859f2>.

${ }^{144}$ Jeremy Stahl, “Top CBP Officer Testifies He's Unsure if 3-Year-Old Is "a Criminal or a National Security Threat" Reuters (July 2019) <https://slate.com/news-and-politics/2019/07/cbp-chief-brianhastings-family-separation-judiciary-hearing-not-mueller.html>.

145 Ibid.

146 Ibid.
} 
legally significant issues in expanding these powers, as well as in the obvious erosion in constitutionally mandated detention protections. ${ }^{147}$

Another possibility as to why this is spreading perhaps relates back to the "wag the dog" idea, that such narratives always, tragically, find a willing audience, and that they can thus serve to distract from other issues. It is not possible to definitively answer the question of motivation, but it is important to ask the question in filtering the narratives that are constantly and quickly evolving in the public arena. Where the political narrative is, itself, as obviously flawed as the anti-migrant messaging discussed throughout this article, then it must be deconstructed, and any legal developments built on this shaky foundation cannot stand. This mandate is that much more compelling when false narratives are causing significant human-rights violations.

This article has demonstrated several scenarios in which anti-migrant narratives have been thematic in the U.S. Through several examples, most prominently those at the U.S.-Mexico Border, it has also demonstrated that false narratives have profound impacts on foundational legal norms, and that this type of political narrative cannot be separated from the legal narrative that results. The transnational prominence of these narratives raises serious concerns for the future endurance of foundational individual-rights legal norms, as well as more imminent concerns for the welfare of the people targeted by these narratives.

Because of the devastating impact that discriminatory political narratives can have, it is critically important that counter-narratives be promulgated and heard. At the time of publication of this article, news had just broken about two mass shootings in the U.S. within 24 hours, and it was too soon after these horrific events to discuss them in detail. A few points, though, are emerging. In El Paso, Texas, 22 people were killed and 25 injured. ${ }^{148}$ In Dayton, Ohio, where early reports suggested that nine people were killed and others wounded, the motivation behind the shootings remained unclear. ${ }^{149}$ Police in El Paso, however, which is close to the U.S.-Mexico Border, believed, as of the date of this article, that the shooter, a white U.S. citizen who was captured, wrote and posted a "manifesto" shortly before the attacks. The "manifesto" was "filled with white supremacist language and racist hatred aimed at

${ }^{147}$ In Mrs. L, supra note 116 the ACLU has asserted the current migrant detention scenario violates the Due Process provisions in the U.S. Constitution. See U.S. Const amend V.

148 See Christina Maxouris, et al, "President Trump to Visit El Paso Wednesday, Mayor Says" CNN (5 August 2019), online: <https://www.cnn.com/2019/08/05/us/el-paso-shooting-monday/index.html>.

149 See Meg Wagner, et al, "Live Updates: At Least 31 Killed in U.S. Weekend Mass Shootings" CNN (5 August 2019), online: <https://www.cnn.com/us/live-news/el-paso-dayton-shootings-august2019/index.html> [Wagner].

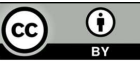


immigrants and Latinos." 150 The "manifesto" also indicated that the person held these beliefs long before Trump became President. ${ }^{151}$ The New York Times reported that the language of the manifesto drew from language used by Trump, such as his comments about the "invasion" at the Border. ${ }^{152}$

Trump quickly condemned both shootings. After the El Paso shootings, Trump condemned "today's hateful act."153 On August 5, 2019, Trump made a speech about the shootings, in which he condemned white supremacy, saying "[i]n one voice our nation must condemn racism, bigotry and white supremacy ... These sinister ideologies must be defeated" and cited "violent video games, mental illness" and "internet bigotry" as contributing factors. ${ }^{154} \mathrm{He}$ did not mention the possibility of his own political narratives being relevant. ${ }^{155}$

Others were not so forgiving of him. Democratic Presidential Candidate Beto O'Rourke, who is from El Paso, bluntly said that Trump is a "white nationalist." $156 \mathrm{He}$ wrote, referring to a post by Trump calling for stronger immigration background checks in response to the shootings, "[o]nly a racist, driven by fear, could witness what took place this weekend-and instead of standing up to hatred, side with a mass murderer's call to make our country more white. We are so much better than

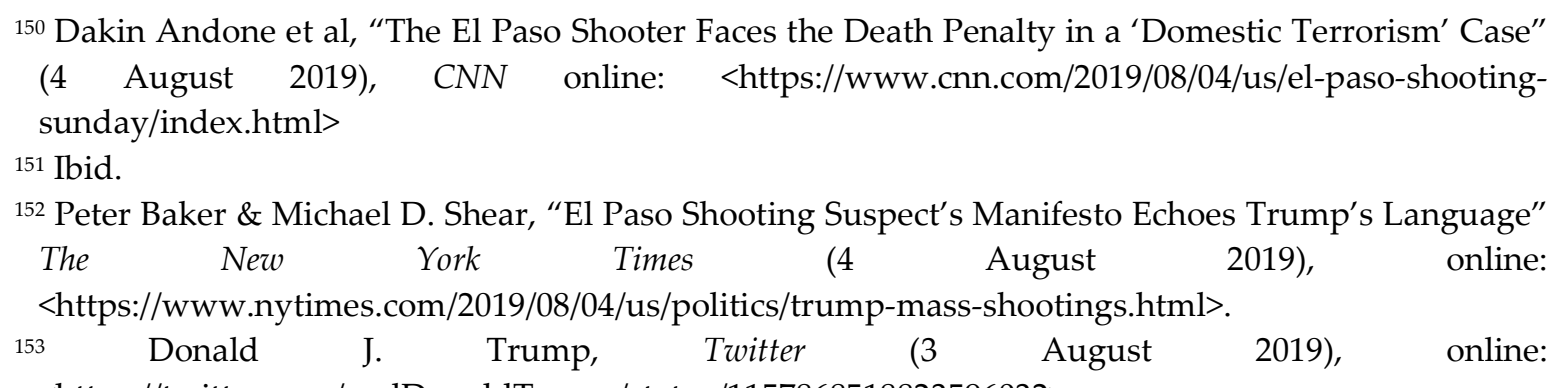
<https://twitter.com/realDonaldTrump/status/1157868518823596032>.

${ }^{154}$ Michael Crowley \& Maggie Haberman, "Trump Condemns White Supremacy but Stops Short of Major Gun Controls" The New York Times (5 August 2019), online: $<$ https://www.nytimes.com/2019/08/05/us/politics/trump-speech-mass-shootings-dayton-elpaso.html>.

155 Ibid; see also Anthony Rivas, “Trump's Language About Mexican Immigrants Under Scrutiny in Wake of El Paso Shooting" ABCNews (4 August 2019), online: <https://abcnews.go.com/US/trumpslanguage-mexican-immigrants-scrutiny-wake-el-paso/story?id=64768566> (among other things, reiterating Trump's laughing response during a rally in May, when he asked how to stop immigrants, and an attendee yelled "shoot them")[Rivas].

156 Caroline Kelly, "Beto O'Rourke: President Donald Trump is a White Nationalist" CNN (4 August 2019), online: <https://www.cnn.com/2019/08/04/politics/beto-orourke-trump-white-nationalistcnntv/index.html>; see also Rivas, supra note 155; see also Beto O’Rourke, Twitter (3 August 2019), online: <https://twitter.com/BetoORourke/status/1157851323796037634> (linking Trump's "racism" to "violence"). 
this president." 157 Democratic Presidential Candidate and U.S. Senator Cory Booker wrote: "When Donald Trump uses words like 'infestation,' 'invasion' and 's--thole countries'...when he refuses to condemn Neo-Nazis and white supremacists...Trump is giving license to this kind of violence. He's responsible." 158 Democratic Presidential Candidate and U.S. Senator Bernie Sanders drew a stark parallel with history, writing: "most of my father's family was brutally murdered at the hands of Hitler's white supremacist regime-a regime which came to power on a wave of violence and hatred against racial and religious minorities ... We cannot allow that cancer to grow here." 159

Trump did, however, post about the responsibility of the media for "life and safety in our country," saying the "Fake News has contributed greatly to the anger and rage that has built up over many years."160 That same day, Trump posted on Twitter that a bipartisan plan should occur regarding "strong background checks, perhaps marrying... this legislation with desperately needed immigration reform."161 The anti-migrant narratives continue.

\section{REFERENCES}

\section{CONSTITUTIONAL DOCUMENTS}

Canadian Charter of Rights and Freedoms, s 2(b), Part 1 of the Constitution Act, 1982,

being Schedule B to the Canada Act 1982 (UK), 1982, c 11.

U.S. Const. amend I.

U.S. Const amend V.

LEGISLATION

Criminal Code, RSC 1985, c C-46, s 319 (2) (Canada).

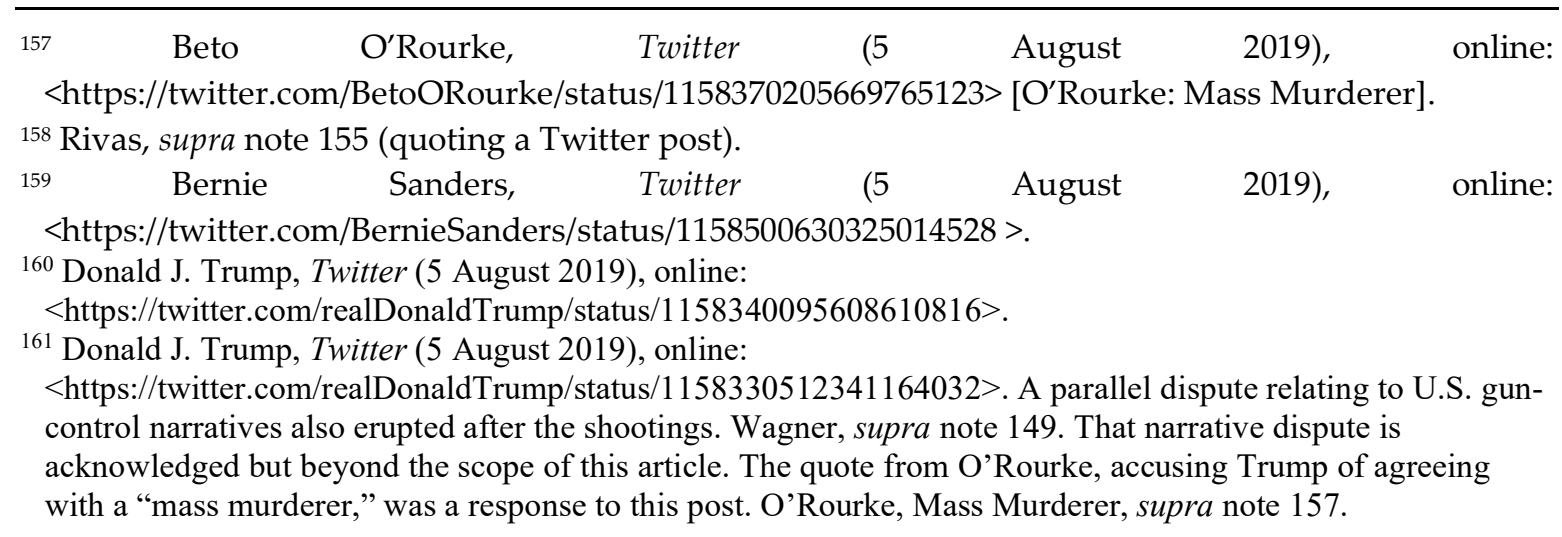




\section{JURISPRUDENCE AND PENDING LITIGATION}

Flores $v$ Barr, No 17-56297 YouTube: United States Court of Appeal for the Ninth Circuit (18 June 2019), online:

$<$ https://www.youtube.com/watch?v=Z2GkDz9yEJA\&t=2423s > (video of oral argument).

International Refugee Assistance Project v Trump, No. 17-1351, 857 F.3d 554 (4th Cir 2017).

Knight First Amendment Institute at Columbia University et al v Trump, No. 18-1691-cv (2nd Cir 2019).

Mrs. L v ICE, No 3:18-cv-00428-DMS-MDD (SD Cal pending)(legal documents found at <https://www.aclu.org/cases/ms-l-v-ice>).

Ocampo v. Enriquez, G.R. Nos. 225973, 225984, 226097, 226116, 226117, 226120 \& 226294, November 8, 2016)(Philippines).

$R v$ Keegstra [1990] 3 SCR 697, [1991] 2 WWR 1 (SCC)(Canada).

Resolutions in Files 3829-2019, 3849-2019 and 3881-2019. "Third Safe Country", Expedientes Acumulados 3829-2019, 3849-2019 y 3881-2019, Corte de Constitucionalidad República de Guatemala, C.A. (15 July 2019), online: $<$ https://cc.gob.gt/2019/07/15/resoluciones-en-expedientes-3829-2019-3849/> (translated via the website's translation tool).

Sierra Club v Trump, Case No. 19-cv-00892-HSG (ND Cali 2019) at 54.

Trump v Hawaii, No 17-965, 585 U.S. _ (2018).

Trump v Sierra Club, 588 U. S. (2019).

\section{SECONDARY MATERIAL: MONOGRAPHS/BOOKS}

Duffy, Maureen. Detention of Terrorism Suspects: Political Discourse and Fragmented Practices (Oxford: Hart 2018).

Duffy, Maureen T. The U.S. Immigration Detentions in the War on Terror: Impact on the Rule of Law (unpublished Master's thesis, McGill University, 2005)(focusing on the "special-interest" detainees in the U.S. after the 9/11 attacks).

Lockhart, Michele, ed, President Donald Trump and His Political Discourse: Ramifications of Rhetoric via Twitter (New York: Routledge 2019).

Lytle Hernandez, Kelly. City of Inmates: Conquest, Rebellion, and the Rise of Human Caging in Los Angeles, 1771-1965 (UNC Press 2017).

Noah, Trevor. Born a Crime (Canada: Penguin/Random House/Doubleday Canada 2016).

Thanouli, Eleftheria. Wag the Dog: A Study on Film and Reality in the Digital Age (London: Bloomsbury Academic 2013). 
SECONDARY MATERIAL: ACADEMIC ARTICLES/BOOK CHAPTERS Bakiner, Onur. "'These are Ordinary Things': Regulation of Death under the AKP Regime," in Banu Bargu, ed., Turkey's Necropolitical Laboratory: Democracy, Violence and Resistance (forthcoming October 2019, Edinburgh University Press), as presented at the Canadian Law and Society Association conference, June 2019.

Bangalore Prakash, Saikrishna. "The Imbecilic Executive” (2013) 99 Va. L. Rev. 1361 Brubaker, Rogers. "Between Nationalism and Civilizationism: The European

Populist Moment in Comparative Perspective" (2017) 40:8 Ethnic and Racial Studies 1191.

Dahab, Ramsey \& Omori, Marisa. “Homegrown Foreigners: How Christian Nationalism and Nativist Attitudes Impact Muslim Civil Liberties" (2018) 42:10 Ethnic and Racial Studies 1727.

Gatmaytan, Dante. "Judicial Historical Revisionism," forthcoming, as presented at the conferences of the Law and Society Association of Australia and New Zealand and the Canadian Law and Society Association.

Hughey, Matthew W. "Bad Hombres? The Implicit and Explicit Racialization of Immigration," (2017) 41(1) Humanity and Society 127-129 (an introduction to a series of book reviews).

Light, Michael T. \& Miller, Ty. “Does Undocumented Immigration Increase Violent Crime?" (2018) 56:2 Criminology 370 at 370.

Mathews, Melissa K. "Restoring the Imperial Presidency: An Examination of President Bush's New Emergency Powers," (2001-2002) 23 Hamline J. Pub. Law 325.

Shernhev, Saul R. "Political Narratives and Political Reality," (2006) 27:3

International Political Science Review 245.

\section{SECONDARY MATERIAL: GOVERNMENTAL DOCUMENTS/OFFICIAL} STATEMENTS

Executive Office of the President, "Affording Congress an Opportunity To Address Family Separation" Federal Register (25 June 2018), online: $<$ https://www.federalregister.gov/documents/2018/06/25/2018-13696/affordingcongress-an-opportunity-to-address-family-separation>.

Office of Inspector General, "Management Alert -DHS Needs to Address Dangerous Overcrowding and Prolonged Detention of Children and Adults in the Rio 
Grande Valley (Redacted)" Department of Homeland Security (2019), online: $<$ https://www.oig.dhs.gov/sites/default/files/assets/2019-07/OIG-19-51Jul19_.pdf.>.

O'Rourke, Beto. Twitter (3 August 2019), online: $<$ https://twitter.com/BetoORourke/status/1157851323796037634>

O’Rourke, Beto. Twitter (5 August 2019), online: <https://twitter.com/BetoORourke/status/1158370205669765123>.

Pelosi, Nancy. Twitter (29 July 2019), online: <https://twitter.com/SpeakerPelosi/status/1155148508296613889>.

President George W. Bush, "Address to a Joint Session of Congress and the American People" The White House (20 September 2001), online: $<$ https://georgewbushwhitehouse.archives.gov/news/releases/2001/09/200109208.html>.

Sanders, Bernie. Twitter (5 August 2019), online: $<$ https://twitter.com/BernieSanders/status/1158500630325014528>.

Trump, Donald J. Twitter (22 June 2018), online: <https://twitter.com/realDonaldTrump/status/1010156224749408258>.

Trump, Donald J. Twitter (25 October 2018), online: $<$ https://twitter.com/realDonaldTrump/status/1055527191235227648>.

Trump, Donald J. Twitter (29 October 2018), online: <https://twitter.com/realDonaldTrump/status/1056919064906469376>.

Trump, Donald J. Twitter (30 March 2019), online: <https://twitter.com/realDonaldTrump/status/1112091249153134598 >.

Trump, Donald J. Twitter (27 June 2019), online: $<$ https://twitter.com/realDonaldTrump/status/1155223906959147008>.

Trump, Donald J. Twitter (14 July 2019), online: $<$ https://twitter.com/realDonaldTrump/status/1150381394234941448> (beginning a thread of three tweets).

Trump, Donald J. Twitter (23 July 2019), online: $<$ https://twitter.com/realDonaldTrump/status/1153641906699681795> (beginning of a thread).

Trump, Donald J. Twitter (26 July 2019), online: <https://twitter.com/realDonaldTrump/status/1154883345546928128>.

Trump, Donald J. Twitter (27 July 2019), online: $<$ https://twitter.com/realDonaldTrump/status/1155073965880172544>.

Trump, Donald J. Twitter (3 August 2019), online: <https://twitter.com/realDonaldTrump/status/1157868518823596032>. 
Trump, Donald J. Twitter (5 August 2019), online: <https://twitter.com/realDonaldTrump/status/1158340095608610816>.

Trump, Donald J. Twitter (5 August 2019), online: <https://twitter.com/realDonaldTrump/status/1158330512341164032>.

United States Customs and Border Protection, "Criminal Alien Statistics Fiscal Year 2019" U.S. Department of Homeland Security, online:

$<$ https://www.cbp.gov/newsroom/stats/cbp-enforcement-statistics/criminal-alienstatistics>.

United States Department of Justice, Office of the Inspector General, The September 11 Detainees: A Review of the Treatment of Aliens Held on Immigration Charges in Connection with the Investigation of the September 11 Attacks (June 2003) c. 4, U.S. Department of Justice, Office of the Inspector General.

United States Federal Register, "Declaring a National Emergency Concerning the Southern Border of the United States," Proclamation 9844 National Archives (15 February 2019), online:

$<$ https://www.federalregister.gov/documents/2019/02/20/2019-03011/declaring-anational-emergency-concerning-the-southern-border-of-the-united-states $>$.

White House, The. Twitter (26 July 2019), online: $<$ https://twitter.com/WhiteHouse/status/1154861528539160576>. SECONDARY MATERIAL: ESSAYS AND ONLINE EXPERT COMMENTARY

Akhavan, Payam. "Finding Empathy in the Age of Rage" Open Canada (22 May 2019) $<$ https://www.opencanada.org/features/finding-empathy-age-rage/>.

American Academy of Pediatrics, "AAP Statement on Executive Order on Family Separation" American Academy of Pediatrics (20 June 2018), online: $<$ https://www.aap.org/en-us/about-the-aap/aap-press-room/Pages/AAPStatement-on-Executive-Order-on-Family-Separation.aspx>.

Amnesty International, "Fleeing for Our Lives: Central American Migrant Crisis" Amnesty International, online: <https://www.amnestyusa.org/fleeing-for-our-livescentral-american-migrant-crisis/>.

Border Network for Human Rights, "The State of Human Rights at the U.S.-Mexico Border" BNHR (June 2019), online: <http://bnhr.org/wpcontent/uploads/2019/06/BNHR-Abuse-Documentation-Campaing-Report-2019.pdf>.

“Democratic Decay \& Renewal: Bringing Democracy Defenders Together," online: $<$ https://www.democratic-decay.org/>. 
Duffy, Maureen. “'A Complete Corruption in Morality': U.S. Family Separation and the Canada-U.S. Safe Third Country Agreement" JURIST (17 July 2018), online: <https://www.jurist.org/commentary/2018/07/maureen-duffy-corrupt-morality/>.

Gonzalez Barrera, Ana. "What we know about illegal immigration from Mexico" Fact Tank: Pew Research Center (28 June 2019), online: $<$ https://www.pewresearch.org/fact-tank/2019/06/28/what-we-know-aboutillegal-immigration-from-mexico/>.

Henein, Maria. “Rule of Law" Ideacity 2019, online: <https://ideacity.ca/video/mariehenein-rule-of-law/> (video).

International Rescue Committee, "Migrants, Asylum Seekers, Refugees and Immigrants: What's the Difference?" IRC (22 June 2018), online: $<$ https://www.rescue.org/article/migrants-asylum-seekers-refugees-andimmigrants-whats-difference>.

Krogstad, Jens Manuel. et al, "5 Facts About Illegal Immigration in the U.S.” Fact Tank: Pew Research Center (12 June 2019), online: $<$ https://www.pewresearch.org/fact-tank/2019/06/12/5-facts-about-illegalimmigration-in-the-u-s/>.

Lytle Hernandez, Kelly. "How Crossing the US-Mexico Border Became a Crime" The Conversation (30 April 2017) online: <https://theconversation.com/how-crossingthe-us-mexico-border-became-a-crime-74604>.

Orwell, George. "Politics and the English Language" (first published London: Horizon 1946, reproduced numerous times since), online: $<$ http://www.orwell.ru/library/essays/politics/english/e_polit>.

Pompa, Cynthia. "Immigrant Kids Keep Dying in CBP Detention Centers, and DHS Won't Take Accountability" ACLU (24 June 2019), online: $<$ https://www.aclu.org/blog/immigrants-rights/immigrants-rights-anddetention/immigrant-kids-keep-dying-cbp-detention>.

Romero, Anthony D., “Donald Trump: A One-Man Constitutional Crisis” ACLU (13 July 2016), online: <https://www.aclu.org/issues/executive-branch/donald-trumpone-man-constitutional-crisis $>$.

United Nations Refugee Agency, “Central America Refugee Crisis” United Nations High Commissioner for Refugees, online:

$<$ https://www.unrefugees.org/emergencies/central-america/>.

United Nations Office for the Coordination of Humanitarian Affairs, "About OCHA Syria," UNOCHA, online: <https://www.unocha.org/syrian-arab-republic/aboutocha-syria>. 


\section{SECONDARY MATERIAL: MEDIA AND OTHER SOURCES}

“Donald Trump Calls Syrian Refugees “The Great Trojan Horse Of All Time'”

Huffington Post <https://www.huffingtonpost.ca/entry/donald-trump-calls-syrianrefugees-the-great-trojan-horse-of-all-time_n_5b507acbe4b00e8c8eb7259b>. "Guatemala Signs Migration Deal with US After Trump Threats" BBC (27 July 2019), online: <https://www.bbc.com/news/world-latin-america-49134544>.

"Trump Says Cummings Lied About Conditions in Migrant Detention Facilities. Did He?" PBS News Hour (29 July 2019), online:

https://www.pbs.org/newshour/show/trump-says-cummings-lied-aboutconditions-in-migrant-detention-facilities-did-he>.

“Trump Says He Doesn't See White Nationalism as a Rising Global Threat After New Zealand Shooting" Time (15 March 2019), online:

$<$ https://time.com/5552850/donald-trump-white-nationalism-global-threat-newzealand/>.

Alberta, Tim. “The Democrats' Dilemma” Politico (8 March 2019), online: $<$ https://www.politico.com/magazine/story/2019/03/08/ilhan-omar-dean-phillipsminnesota-democratic-party-225696>.

Andone, Dakin, et al. "The El Paso Shooter Faces the Death Penalty in a 'Domestic Terrorism' Case" (4 August 2019), CNN online:

$<$ https://www.cnn.com/2019/08/04/us/el-paso-shooting-sunday/index.html>.

Associated Press, “'Tragic Conditions': Migrant Kids at Texas Border Facility

Neglected and Lack Food, Water and Sanitation" CBC (21 June 2019), online:

$<$ https://www.cbc.ca/news/world/texas-el-paso-migrant-children-neglect-

$1.5185329>$.

Associated Press, “Trump Downplays Threat of White Nationalism Following New Zealand Massacre" CBC (15 March 2019), online:

$<$ https://www.cbc.ca/news/world/trump-new-zealand-white-identity-1.5059127>.

Associated Press, “U.S. Fires Tear Gas Across Mexico Border to Stop Migrants” NBC

News (1 January 2019), online:

$<$ https://www.nbcnews.com/storyline/immigration-border-crisis/u-s-fires-teargas-across-mexico-border-stop-migrants-n953641>.

Aymer, Rev. Dr. Margaret \& Nasrallah, Laura. “What Jeff Sessions Got Wrong When Quoting the Bible" Washington Post (15 June 2018), online:

$<$ https://www.washingtonpost.com/news/acts-of-faith/wp/2018/06/15/what-jeffsessions-got-wrong-when-quoting-the-bible/?utm_term=.1927398859f2>. 
Baker, Peter \& Shear, Michael D. “El Paso Shooting Suspect's Manifesto Echoes Trump's Language" The New York Times (4 August 2019), online: $<$ https://www.nytimes.com/2019/08/04/us/politics/trump-mass-shootings.html>.

Baltimore Sun Editorial Board, "Better to Have a Few Rats Than to be One" Baltimore Sun (28 July 2019), <https://www.baltimoresun.com/opinion/editorial/bs-ed-0728trump-baltimore-20190727-k6ac4yvnpvcczlaexdfglifada-story.html>.

Barry, Orla. “In Orbán's Hungary, Refugees Are Unwelcome - So Are Those Who Try to Help" PRI's the World (11 February 2019), online: $<$ https://www.pri.org/stories/2019-02-11/orban-s-hungary-refugees-areunwelcome-so-are-those-who-try-help>.

Campoy, Ana. “US Officials Must Now Say 'Illegal Aliens,' Not 'Undocumented Immigrants'” QZ (25 July 2018), online: <https://qz.com/1336110/its-illegalaliens-not-undocumented-immigrants-says-the-us-department-of-justice/>.

Carasik, Lauren. "Trump's Safe Third Country Agreement With Guatemala Is a Lie" Foreign Policy (30 July 2019) online:

$<$ https://foreignpolicy.com/2019/07/30/trumps-safe-third-country-agreementwith-guatemala-is-a-lie/>.

Cass, Robert. “The Origins of the Term 'Windy City' Have Been Misreported (Again)" Chicago Reader (21 November 2008), online: $<$ https://www.chicagoreader.com/Bleader/archives/2008/11/21/the-origins-of-theterm-windy-city-have-been-misreported-again>.

Collins, Michael \& Jackson, David. “Trump Says Detention Facilities ‘Beautifully Run’ After Report Describes Dangerous Conditions” USA Today (5 July 2019), online: <https://www.usatoday.com/story/news/politics/2019/07/05/immigrationtrump-defends-beautifully-run-detention-facilities/1660455001/>.

Cooper, Anderson. Interview, “Donald Trump: 'I Think Islam Hates Us' YouTube: CNN (9 March 2016), online: <https://www.youtube.com/watch?v=C-Zj0tfZY6o>.

Crowley \& Maggie Haberman, "Trump Condemns White Supremacy but Stops Short of Major Gun Controls" The New York Times (5 August 2019), online:

<https://www.nytimes.com/2019/08/05/us/politics/trump-speech-mass-shootingsdayton-el-paso.html>.

Duggan, Paul \& Jouvenal, Justin. “Neo-Nazi Sympathizer Pleads Guilty to Federal Hate Crimes for Plowing Car into Crowd of Protesters at 'Unite the Right' rally in Charlottesville" Washington Post (1 April 2019), online: $<$ https://www.washingtonpost.com/local/public-safety/neo-nazi-sympathizerpleads-guilty-to-federal-hate-crimes-for-plowing-car-into-crowd-of-protesters-at- 
unite-the-right-rally-in-charlottesville/2019/03/27/2b947c32-50ab-11e9-8d28f5149e5a2fda_story.html?utm_term=.8f62805e362a>.

Ferreras, Jesse. "Donald Trump: 'I'm a nationalist, OK? Nationalist. Use That Word, Use That Word'" Global News (22 October 2018), online: $<$ https:/globalnews.ca/news/4584546/donald-trump-nationalist-rally-texas/>.

Fox News, "Donald Trump Sits Down With Bill O'Reilly" The O'Reilly Factor (30 March 2011) <https://www.foxnews.com/transcript/donald-trump-sits-downwith-bill-oreilly>.

González- Ramírez, Andrea. “Don't Let Trump's Racist Tweets Distract You From These Immigration Stories" Refinery29 (15 July 2019), online: $<$ https://www.refinery29.com/en-us/2019/07/237856/trump-alexandria-ocasiocortez-racist-tweets-ice-raids-asylum-policy>.

Guardian Staff, "Who is Jair Bonsonaro? Brazil's Far-Right President in his Own Words" The Guardian (29 October 2019), online: <https://www.theguardian.com/world/2018/sep/06/jair-bolsonaro-brazil-tropicaltrump-who-hankers-for-days-of-dictatorship $>$.

Haslett, Cheyenne. "Fact Check: Trump's Claims on Undocumented Immigrant Crime Rates. Here's What the Numbers Show" ABC News (15 January 2019), online: <https://abcnews.go.com/Politics/fact-check-trumps-claims-illegalimmigrant-crime-rates/story? $\mathrm{id}=60311860>$.

Holland, Steve \& Cowan, Richard. "Backing down, Trump agrees to end shutdown without border wall money" Reuters (25 January 2019), online: $<$ https://www.reuters.com/article/us-usa-shutdown/backing-down-trumpagrees-to-end-shutdown-without-border-wall-money-idUSKCN1PJ126>.

Jacobson, Louis. “Donald Trump Says If You're from Syria and a Christian, You Can't Come to the U.S. as a Refugee" (20 July 2015) Politifact, online:

$<$ https://www.politifact.com/truth-o-meter/statements/2015/jul/20/donaldtrump/donald-trump-says-if-youre-syria-and-christianyou-/>.

Keith, Tamara. “Commander-In-Tweet: Trump's Social Media Use and Presidential Media Avoidance" NPR (18 November 2016), online:

<https://www.npr.org/2016/11/18/502306687/commander-in-tweet-trumps-socialmedia-use-and-presidential-media-avoidance $>$.

Kelly, Caroline. "Beto O'Rourke: President Donald Trump is a White Nationalist" CNN (4 August 2019), online: <https://www.cnn.com/2019/08/04/politics/betoorourke-trump-white-nationalist-cnntv/index.html>. 
Kelly, Caroline. “Ocasio-Cortez on Calling Detention Centers 'Concentration Camps': We Have to 'Learn From Our History'” CNN (27 June 2019), online: $<$ https://www.cnn.com/2019/06/27/politics/alexandria-ocasio-cortezconcentration-camps-the-lead-cnntv/index.html>.

Khrebtan-Hörhager, Julia. "Italians First: The New Borders of European Humanity" Europe Now Journal (4 February 2019), online:

$<$ https://www.europenowjournal.org/2019/02/04/italians-first-the-new-bordersof-european-humanity/>.

Kopan, Tal et al. "Separated parents given option for voluntary deportation amid child reunification" CNN (24 June 2018), online:

$<$ https://www.cnn.com/2018/06/24/politics/family-reunification-deportationorders/index.html>.

Levinson, Barry, Dir. Wag the Dog (Baltimore Pictures: 1997).

Maxouris, Christina, et al. "President Trump to Visit El Paso Wednesday, Mayor Says" CNN (5 August 2019), online: <https://www.cnn.com/2019/08/05/us/elpaso-shooting-monday/index.html $>$.

Monbiot, George. "From Trump to Johnson, Nationalists Are on the Rise - Backed by Billionaire Oligarchs" The Guardian (26 July 2019), online:

$<$ https://www.theguardian.com/commentisfree/2019/jul/26/trump-johnsonnationalists-billionaire-oligarchs $>$.

Newport, Frank. “Deconstructing Trump's Use of Twitter” Gallup (16 May 2018), online: <https://news.gallup.com/poll/234509/deconstructing-trumptwitter.aspx>.

Nyhan, Brendan. "Trump Is Taking Credit for Resolving the Crises He Created" Medium (4 June 2019), online: <https://gen.medium.com/trump-is-taking-creditfor-resolving-the-crises-he-created-35e4d720ed04>.

Ortega, Bob. "Trump Said Military Should Shoot Rock-Throwing Migrants. Officials Disagree." CNN (2 November 2018), online: $<$ https://www.cnn.com/2018/11/02/us/officials-dismiss-shooting-rock-throwingmigrants-trump-invs/index.html $>$.

Politico Staff, “Full Text: Trump's Comments on White Supremacists, 'Alt-Left' in Charlottesville" Politico (15 August 2017), online:

$<$ https://www.politico.com/story/2017/08/15/full-text-trump-comments-whitesupremacists-alt-left-transcript-241662>.

Rascoe, Ayesha. "A Year After Charlottesville, Not Much Has Changed For Trump" NPR (11 August 2018), online: <https://www.npr.org/2018/08/11/637665414/ayear-after-charlottesville-not-much-has-changed-for-trump $>$. 
Reuters, "Polish Opposition Warns Refugees Could Spread Infectious Diseases" Reuters (15 October 2015), online: <https://www.reuters.com/article/us-europemigrants-poland/polish-opposition-warns-refugees-could-spread-infectiousdiseases-idUSKCN0S918B20151015>.

Rivas, Anthony. “Trump's Language About Mexican Immigrants Under Scrutiny in Wake of El Paso Shooting" ABCNews (4 August 2019), online: $<$ https://abcnews.go.com/US/trumps-language-mexican-immigrants-scrutinywake-el-paso/story?id=64768566>.

Ruiz, Camila. “The Battle Over the Words Used to Describe migrants" BBC (28 August 2015), online: <https://www.bbc.com/news/magazine-34061097>.

Sacchetti, Maria. “ACLU: U.S. Has Taken Nearly 1,000 Child Migrants from Their Parents Since Judge Ordered Stop to Border Separations" Washington Post (30 July 2019), online: <https://www.washingtonpost.com/immigration/aclu-us-hastaken-nearly-1000-child-migrants-from-their-parents-since-judge-ordered-stopto-border-separations/2019/07/30/bde452d8-b2d5-11e9-8949-

5f36ff92706e_story.html?noredirect=on\&utm_term=.7f2d9db9036f $>$.

Sergent, James et al. "Chilling First-Hand Reports of Migrant Detention Centers Highlight Smell of 'Urine, Feces,' Overcrowded Conditions" USAToday (17 July 2019), online: <https://www.usatoday.com/indepth/news/politics/elections/2019/07/16/migrant-detention-centers-described2019-us-government-accounts/1694638001/>.

Shepardson, David. “Trump Says Family Separations Deter Illegal Immigration” Reuters (13 October 2018), online: <https://www.reuters.com/article/us-usaimmigration-trump/trump-says-family-separations-deter-illegal-immigrationidUSKCN1MO00C>.

Sherman, Wendy R. “Opinion: How to Stop the March to War with Iran The New York Times (15 May 2019), online:

$<$ https://www.nytimes.com/2019/05/15/opinion/stop-iran-war.html>.

Shoichet, Catherine E. "What 7 Statistics Tell Us About Immigration and Crime CNN (8 January 2019), online: <https://www.cnn.com/2018/11/03/us/immigrants-crimenumbers/index.html>.

Stahl, Jeremy. “Top CBP Officer Testifies He's Unsure if 3-Year-Old Is “a Criminal or a National Security Threat" Reuters (July 2019) <https://slate.com/news-andpolitics/2019/07/cbp-chief-brian-hastings-family-separation-judiciary-hearingnot-mueller.html>. 
Taylor, Adam. “Trump Embraces 'Wag the Dog' Politics” Washington Post (31 October 2018), online:

<https://www.washingtonpost.com/world/2018/10/31/trump-embraces-wag-dogpolitics/?utm_term=.3f04fd0eb7e3>.

Thrush, Glenn \& Haberman, Maggie. “Trump Gives White Supremacists an Unequivocal Boost" The New York Times (15 August 2017), online:

$<$ https://www.nytimes.com/2017/08/15/us/politics/trump-charlottesville-whitenationalists.html?mcubz $=0>$.

Wagner, Meg, et al. “Live Updates: At Least 31 Killed in U.S. Weekend Mass Shootings" CNN (5 August 2019), online: <https://www.cnn.com/us/live-news/elpaso-dayton-shootings-august-2019/index.html>.

Wagner, Meg et al. "What's Happening at the U.S. Border" CNN (22 June 2018), online: <https:/www.cnn.com/politics/live-news/immigration-border-childrenseparation/h_5652f6b137eaba6711e304f376476c94>.

Wiktionary, <https://en.m.wiktionary.org/wiki/full_of_hot_air>. 